\title{
Vibrational Structure of Monosubstituted Octahydrosilasesquioxanes
}

\author{
Claudia Marcolli and Gion Calzaferri* \\ Department of Chemistry and Biochemistry, University of Berne, Freiestrasse 3, 3000 Berne 9, Switzerland
}

Received: February 28, $1997^{\otimes}$

\begin{abstract}
The IR and Raman spectra of the monosubstituted hydrosilasesquioxanes $\mathrm{RH}_{7} \mathrm{Si}_{8} \mathrm{O}_{12}, \mathrm{R}=\mathrm{Co}(\mathrm{CO})_{4}, \mathrm{Ph}$, $\mathrm{CH}=\mathrm{CHPh}$, and $\mathrm{CH}_{2} \mathrm{CH}_{2} \mathrm{Ph}$, have been analyzed by spectral correlation and a normal coordinate analysis. They were treated as a superposition of the spectra of the siloxane cage and the substituent. The molecules $\mathrm{PhH}_{7} \mathrm{Si}_{8} \mathrm{O}_{12},(\mathrm{PhCH}=\mathrm{CH}) \mathrm{H}_{7} \mathrm{Si}_{8} \mathrm{O}_{12}$, and $\left(\mathrm{PhCH}_{2} \mathrm{CH}_{2}\right) \mathrm{H}_{7} \mathrm{Si}_{8} \mathrm{O}_{12}$ have allowed the investigation of the organicsubstituted siloxane cage $\mathrm{CH}_{7} \mathrm{Si}_{8} \mathrm{O}_{12}$, contributing each a case of an $\mathrm{Si}-\mathrm{C}_{\text {phenyl }}, \mathrm{Si}-\mathrm{C}_{\text {vinyl }}$, and $\mathrm{Si}-\mathrm{C}_{\text {alkyl }}$ bond, respectively. The force constants of the different $\mathrm{Si}-\mathrm{C}$ bonds were related to the $\mathrm{Si}-\mathrm{C}$ bond orders and extrapolated for $\mathrm{Si}-\mathrm{C}_{\text {acetyl }}$ of $(\mathrm{PhC} \equiv \mathrm{CH}) \mathrm{H}_{7} \mathrm{Si}_{8} \mathrm{O}_{12}$, which is not yet available. The inorganic-substituted hydrosilasesquioxane $\left[\mathrm{Co}(\mathrm{CO})_{4}\left(\mathrm{H}_{7} \mathrm{Si}_{8} \mathrm{O}_{12}\right)\right]$ could be analyzed the same way as the organic-substituted compounds and showed a similar pattern for the siloxane cage vibrations. Although most spectral features of the siloxane cages could be understood assuming a local $C_{3 v}$ symmetry, vibrations indicating a lower symmetry occurred in all monosubstituted compounds and could be attributed to vibrational coupling with modes of the substituent. Especially the totally symmetric ring-opening vibration at $456 \mathrm{~cm}^{-1}$ in $\mathrm{H}_{8} \mathrm{Si}_{8} \mathrm{O}_{12}$ showed a specific dependence on the different substituents.
\end{abstract}

\section{Introduction}

Octasilasesquioxanes are members of the cage-shaped oligosilasesquioxanes of the general formula $\left(\mathrm{RSiO}_{3 / 2}\right)_{2 n}(n=2$, $3,4, \ldots){ }^{1}$ They show a cube-shaped $\mathrm{Si}_{8} \mathrm{O}_{12}$ unit as illustrated in Scheme 1. During the past few years an increasing number of organo- or organometallo-functionalized silasesquioxanes have become available. They are discussed as oligomeric supramolecular materials, ${ }^{2,3}$ as sources for new organosiliceous polymers, ${ }^{4,5}$ and as precursors to organolithic macromolecular materials (OMM's) ${ }^{6-8}$ or hybrid inorganic-organic materials. ${ }^{9-11}$ Moreover, it has been shown that atomic hydrogen can be encapsulated stably in the $\mathrm{Si}_{8} \mathrm{O}_{12}$ cage. ${ }^{12}$ Hydrosilasesquioxanes $(\mathrm{R}=\mathrm{H})$ have been fruitfully viewed as readily available model compounds for studying specific aspects of zeolites or silica surfaces. ${ }^{13-18}$ Especially $\mathrm{H}_{8} \mathrm{Si}_{8} \mathrm{O}_{12}$ has been thoroughly investigated by X-ray and neutron diffraction, ${ }^{19,20}$ as well as $\mathrm{NMR}^{21}$ and vibrational spectroscopies. ${ }^{14,22}$ Hydrosilation of $\mathrm{H}_{8} \mathrm{Si}_{8} \mathrm{O}_{12}$ leads to monosubstituted and higher substituted octanuclear silasesquioxanes, ${ }^{23-25}$ which can be separated by size exclusion liquid chromatography. ${ }^{26}$ The compounds $\mathrm{RH}_{7} \mathrm{Si}_{8} \mathrm{O}_{12}$ with $\mathrm{R}$ $=\mathrm{Co}(\mathrm{CO})_{4}, \mathrm{CH}=\mathrm{CHPh}$, and $\mathrm{CH}_{2} \mathrm{CH}_{2} \mathrm{Ph}$ illustrated in Scheme 1 have been synthesized by this method. ${ }^{27,28} \mathrm{PhH}_{7} \mathrm{Si}_{8} \mathrm{O}_{12}$ in contrast was obtained starting from a mixture of $\mathrm{HSiCl}_{3}$ and $\mathrm{PhSiCl}_{3}{ }^{29}\left(\mathrm{PhCH}_{2} \mathrm{CH}_{2}\right) \mathrm{H}_{7} \mathrm{Si}_{8} \mathrm{O}_{12}, \mathrm{PhH}_{7} \mathrm{Si}_{8} \mathrm{O}_{12}$, and $(\mathrm{PhCH}=\mathrm{CH})-$ $\mathrm{H}_{7} \mathrm{Si}_{8} \mathrm{O}_{12}$ form a series of molecules composed of a siloxane cage, which is connected to a phenyl group by a $\mathrm{Si}-\mathrm{C}_{\text {alkyl }}, \mathrm{Si}-$ $\mathrm{C}_{\text {phenyl }}$, and $\mathrm{Si}-\mathrm{C}_{\text {vinyl }}$ bond, respectively. $(\mathrm{PhC} \equiv \mathrm{CH}) \mathrm{H}_{7} \mathrm{Si}_{8} \mathrm{O}_{12}$, which is not available yet, would complete this series by contributing the case of the $\mathrm{Si}-\mathrm{C}_{\text {acetyl }}$ bond. We are interested in the vibrational structure of these molecules for theoretical and practical reasons. The theoretical interest stems from their structural similarity with characteristic building elements of zeolites. This has allowed transfer of force constants determined for $\mathrm{H}_{8} \mathrm{Si}_{8} \mathrm{O}_{12}$ to these extended structures. ${ }^{14}$ The notion of ringopening vibrations, which was introduced for $O_{h}-\mathrm{H}_{8} \mathrm{Si}_{8} \mathrm{O}_{12}$, opened a gate for studying the pore-opening vibrations, which are believed to play an important role in the dynamics and the

\footnotetext{
* To whom correspondence should be addressed.

${ }^{\otimes}$ Abstract published in Advance ACS Abstracts, June 1, 1997.
}

SCHEME 1: Investigated Monosubstituted Octahydrosilasesquioxanes $\mathrm{RH}_{7} \mathrm{Si}_{8} \mathrm{O}_{12}$

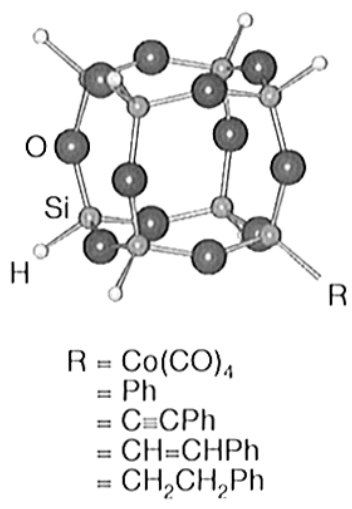

transport properties of zeolites. ${ }^{15} \mathrm{H}_{8} \mathrm{Si}_{8} \mathrm{O}_{12}, \mathrm{D}_{8} \mathrm{Si}_{8} \mathrm{O}_{12}$, and $\mathrm{H}_{10^{-}}$ $\mathrm{Si}_{10} \mathrm{O}_{15}$ have therefore been thoroughly investigated by IR, Raman, and INS (inelastic neutron scattering) spectroscopies. ${ }^{22}$ Moreover, IR and Raman spectroscopies provide an important tool for the identification and characterization of silasesquioxanes. The vibrational structure of $\mathrm{PhH}_{7} \mathrm{Si}_{8} \mathrm{O}_{12}$ has been discussed in detail on the basis of a normal coordinate analysis. ${ }^{29}$ For $(\mathrm{PhCH}=\mathrm{CH}) \mathrm{H}_{7} \mathrm{Si}_{8} \mathrm{O}_{12}$ and $\left(\mathrm{PhCH}_{2} \mathrm{CH}_{2}\right) \mathrm{H}_{7} \mathrm{Si}_{8} \mathrm{O}_{12}$ a preliminary analysis has been given in ref 30 . It was shown that the IR and Raman spectra of the investigated compounds are best understood as superpositions of the spectra of the siloxane cages and the substituents.

In this work the analysis of monosubstituted hydrosilasesquioxanes will be extended to an inorganic-substituted octahydrosilasesquioxane. In $\left[\mathrm{Co}(\mathrm{CO})_{4}\left(\mathrm{H}_{7} \mathrm{Si}_{8} \mathrm{O}_{12}\right)\right]$ the $\mathrm{Co}(\mathrm{CO})_{4}$ substituent is connected to the siloxane cage by a $\mathrm{Si}-\mathrm{Co}$ bond. The IR and Raman spectra of this molecule will be treated the same way as the ones of the organic-substituted compounds. The investigated $\mathrm{RH}_{7} \mathrm{Si}_{8} \mathrm{O}_{12}$ molecules, $\mathrm{R}=\mathrm{Co}(\mathrm{CO})_{4}, \mathrm{Ph}$, $\mathrm{CH}=\mathrm{CHPh}$, and $\mathrm{CH}_{2} \mathrm{CH}_{2} \mathrm{Ph}$, form a good basis for a comparison of the vibrations of the substituted and unsubstituted siloxane cages. Special attention will be paid to the ring-opening vibrations. Moreover, the organic-substituted molecules allow a comparison of the $\mathrm{Si}-\mathrm{C}_{\text {alkyl }}, \mathrm{Si}-\mathrm{C}_{\text {vinyl }}$, and $\mathrm{Si}-\mathrm{C}_{\text {phenyl }}$ bonds. 

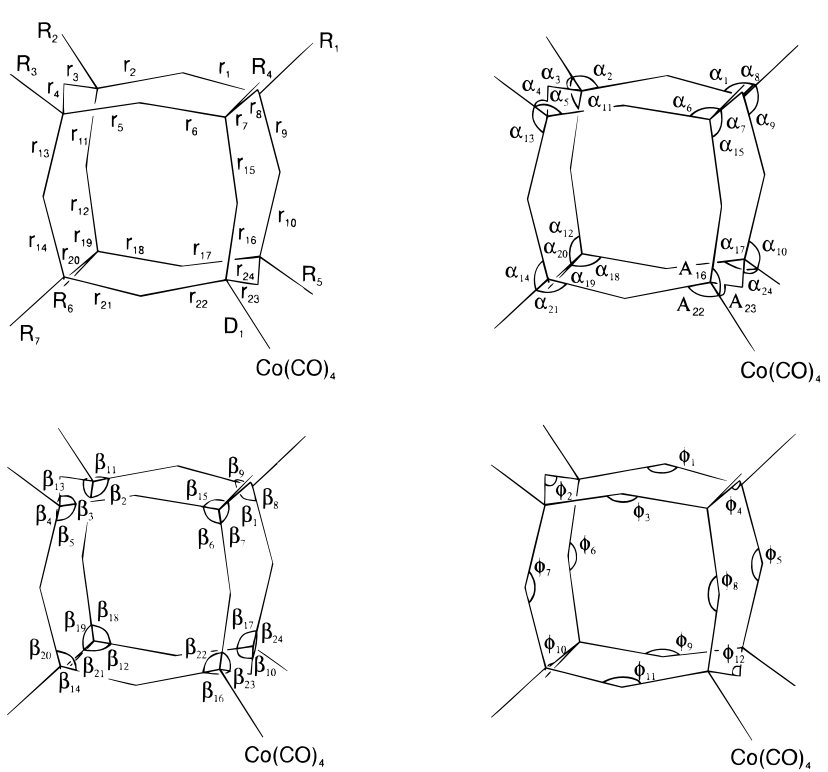

Figure 1. Numbering of the internal coordinates of the siloxane cage $\mathrm{H}_{7} \mathrm{Si}_{8} \mathrm{O}_{12}$.

TABLE 1: Bond Lengths (̊̊) and Bond Angles (deg) for $\left[\mathrm{Co}(\mathrm{CO})_{4}\left(\mathrm{H}_{7} \mathrm{Si}_{8} \mathrm{O}_{12}\right)\right]$

\begin{tabular}{llll}
\hline $\begin{array}{c}\text { internal } \\
\text { coordinates }\end{array}$ & values & \multicolumn{1}{c}{$\begin{array}{c}\text { internal } \\
\text { coordinates }\end{array}$} & values \\
\hline$R(\mathrm{Si}-\mathrm{H})$ & 1.48 & $T\left(\mathrm{Co}-\mathrm{C}_{\mathrm{ax}}\right)$ & 1.809 \\
$r(\mathrm{Si}-\mathrm{O})$ & 1.62 & $S\left(\mathrm{Co}-\mathrm{C}_{\mathrm{eq}}\right)$ & 1.788 \\
$\alpha(\mathrm{O}-\mathrm{Si}-\mathrm{H})$ & 109.5 & $t\left(\mathrm{C}_{\mathrm{ax}}-\mathrm{O}\right)$ & 1.128 \\
$\beta(\mathrm{O}-\mathrm{Si}-\mathrm{H})$ & 109.5 & $s\left(\mathrm{C}_{\mathrm{eq}}-\mathrm{O}\right)$ & 1.131 \\
$\phi(\mathrm{Si}-\mathrm{O}-\mathrm{Si})$ & 148.4 & $\omega\left(\mathrm{Si}-\mathrm{Co}-\mathrm{C}_{\mathrm{eq}}\right)$ & 83.9 \\
$D(\mathrm{Si}-\mathrm{Co})$ & 2.285 & $\epsilon\left(\mathrm{C}_{\mathrm{eq}}-\mathrm{Co}-\mathrm{C}_{\mathrm{ax}}\right)$ & 96.1
\end{tabular}

The $\mathrm{Si}-\mathrm{C}$ frequencies and force constants shall be related to the bond orders as determined by an EHMO calculation and extrapolated for $\mathrm{Si}-\mathrm{C}_{\text {acetyl }}$.

\section{Experimental Section}

Synthesis. The synthesis and purification of the investigated monosubstituted octahydrosilasesquioxanes are described in refs 23 and $27-30$.

Spectroscopy. The IR transmission spectra were measured with a BOMEM DA3.01 FTIR spectrometer equipped with a liquid nitrogen-cooled MCT detector $\left(500-5000 \mathrm{~cm}^{-1}\right)$, a liquid helium-cooled $\mathrm{CuGe}$ detector $\left(350-4000 \mathrm{~cm}^{-1}\right)$, and a DTGS detector $\left(10-670 \mathrm{~cm}^{-1}\right)$. A KBr beam splitter was applied for measurements above $\sim 650 \mathrm{~cm}^{-1}$ whereas in the range 350 to $\sim 700 \mathrm{~cm}^{-1}$ a $3 \mu \mathrm{m}$ Mylar beam splitter was used. The spectrum of $\left(\mathrm{PhCH}_{2} \mathrm{CH}_{2}\right) \mathrm{H}_{7} \mathrm{Si}_{8} \mathrm{O}_{12}$ was measured in $\mathrm{CCl}_{4}$ and pentane $\left(960-650 \mathrm{~cm}^{-1}\right.$ ) with the MCT (above $960 \mathrm{~cm}^{-1}$ ) and the $\mathrm{CuGe}$ detectors and a resolution of $0.5 \mathrm{~cm}^{-1}$. $(\mathrm{PhCH}=$ $\mathrm{CH}) \mathrm{H}_{7} \mathrm{Si}_{8} \mathrm{O}_{12}$ was measured in $\mathrm{CCl}_{4}$ and heptane (930-670 $\mathrm{cm}^{-1}$ ) with the MCT detector (above $670 \mathrm{~cm}^{-1}$, resolution = $0.5 \mathrm{~cm}^{-1}$ ) and the DTGS detector (resolution $=2 \mathrm{~cm}^{-1}$ ). $\left[\mathrm{Co}(\mathrm{CO})_{4}\left(\mathrm{H}_{7} \mathrm{Si}_{8} \mathrm{O}_{12}\right)\right]$ was measured in $\mathrm{CCl}_{4}$ with the MCT (above $824 \mathrm{~cm}^{-1}$, resolution $=1 \mathrm{~cm}^{-1}$ ) and the DTGS detector (below $650 \mathrm{~cm}^{-1}$, resolution $=2 \mathrm{~cm}^{-1}$ ). Between 824 and 650 $\mathrm{cm}^{-1}$ the spectrum was interpolated. The detailed measuring conditions for $\left(\mathrm{C}_{6} \mathrm{H}_{13}\right) \mathrm{H}_{7} \mathrm{Si}_{8} \mathrm{O}_{12}$ are found in ref 28 and for $\mathrm{PhH}_{7}$ $\mathrm{Si}_{8} \mathrm{O}_{12}$ in ref 29.

Fourier-transform Raman spectra were recorded with the Bomem Raman accessory of the same spectrometer. The interferometer was equipped with a quartz beam splitter and a liquid nitrogen-cooled InGaAs detector. The continuous-wave $\mathrm{Nd}^{3+}$ :YAG laser (Quantronix Model 114) was run in the

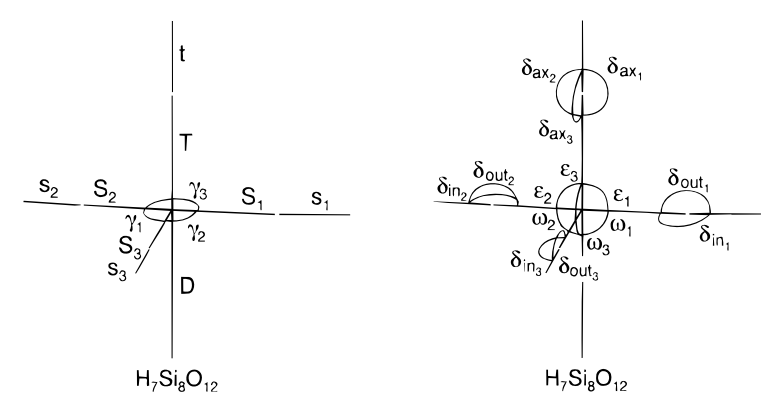

Figure 2. Numbering of the internal coordinates of the carbonyl group $\mathrm{Co}(\mathrm{CO})_{4}$.
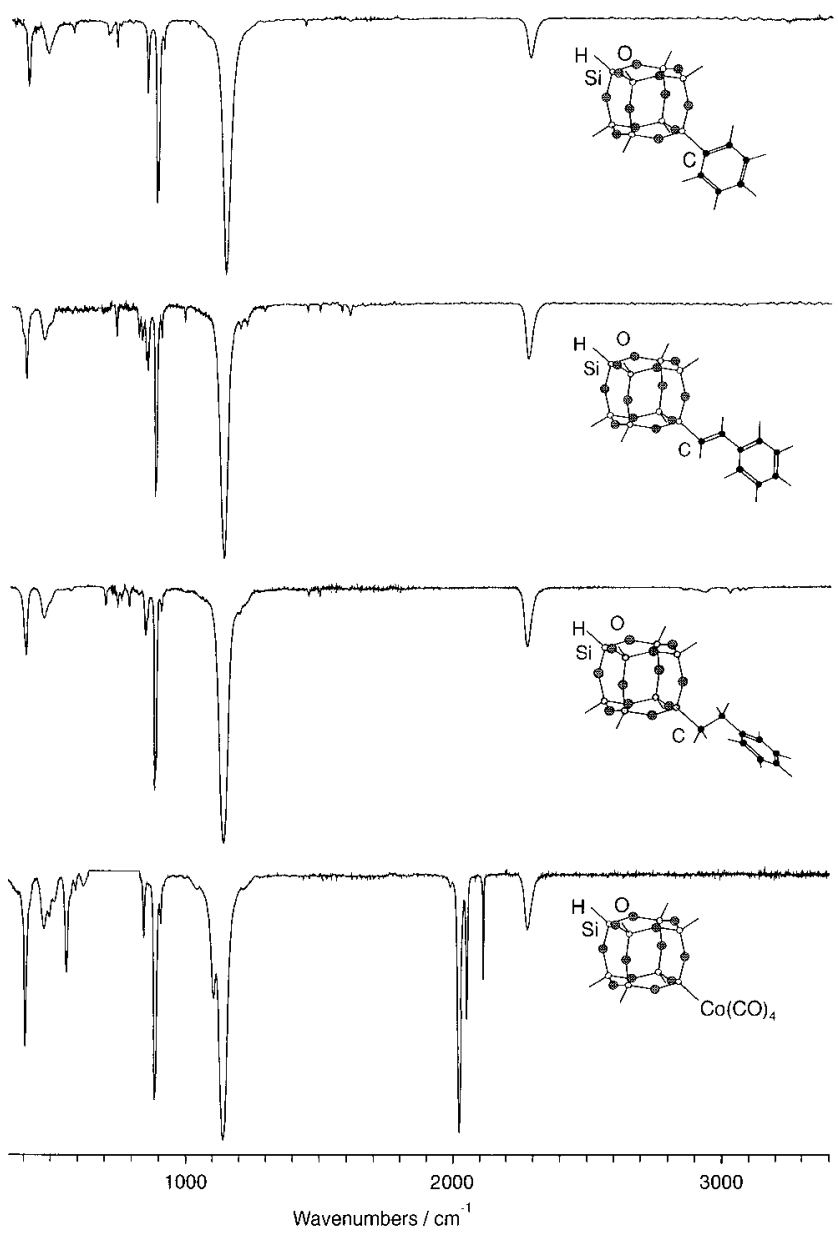

Figure 3. Transmission IR spectra of the investigated monosubstituted octahydrosilasesquioxanes $\mathrm{RH}_{7} \mathrm{Si}_{8} \mathrm{O}_{12}$.

transverse electromagnetic mode TEM $_{00}$ at $9395 \mathrm{~cm}^{-1}$. Rayleigh scattering was blocked by three holographic super notch filters (Kaiser Optical Systems) in a $6^{\circ}$ angle position. A 2 $\mathrm{mm}$ thick anodized aluminum plate with a $1 \mathrm{~mm}$ diameter hole into which the probe was slightly pressed served as sample holder. As the spectrum of $\left[\mathrm{Co}(\mathrm{CO})_{4}\left(\mathrm{H}_{7} \mathrm{Si}_{8} \mathrm{O}_{12}\right)\right]$ was not corrected for filter characteristics, the intensities of the two peaks close to the detection limit at 115 and $109 \mathrm{~cm}^{-1}$ are lowered by the filter characteristics.

Calculations. The vibrational analysis was performed by the Wilson GF matrix method ${ }^{31}$ with the computer program package QCMP0676. ${ }^{32}$ The force field of $\left[\mathrm{Co}(\mathrm{CO})_{4}\left(\mathrm{H}_{7} \mathrm{Si}_{8} \mathrm{O}_{12}\right)\right]$ is based on a force field determined on IR and FT-Raman data of $\mathrm{H}_{8^{-}}$ $\mathrm{Si}_{8} \mathrm{O}_{12}$ and $\mathrm{D}_{8} \mathrm{Si}_{8} \mathrm{O}_{12}$ for the siloxane cage ${ }^{14}$ and on one developed by van den Berg and Oskam for $\left[\mathrm{Co}(\mathrm{CO})_{4}\left(\mathrm{MX}_{3}\right)\right]$ compounds $(\mathrm{M}=\mathrm{Si}, \mathrm{Ge}, \mathrm{Sn} ; \mathrm{X}=\mathrm{H}, \mathrm{D}, \mathrm{F}, \mathrm{Cl}, \mathrm{Br}, \mathrm{I})^{33}$ for the $\mathrm{Co}(\mathrm{CO})_{4}$ group. The bond lengths and angles are listed in Table 1. They correspond for the siloxane cage to the ones used for 


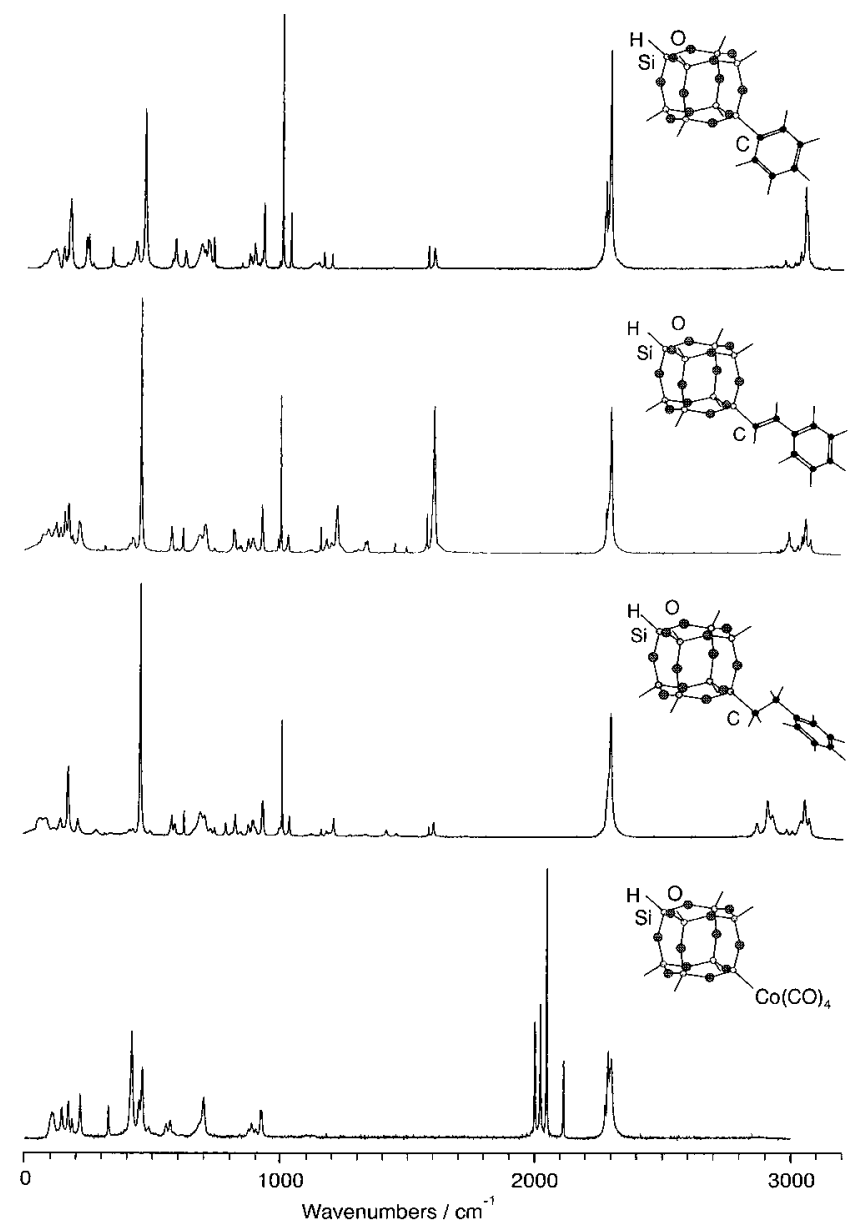

Figure 4. FT-Raman spectra of the investigated monosubstituted octahydrosilasesquioxanes $\mathrm{RH}_{7} \mathrm{Si}_{8} \mathrm{O}_{12}$.

$\mathrm{H}_{8} \mathrm{Si}_{8} \mathrm{O}_{12}$ and for $\mathrm{Co}(\mathrm{CO})_{4}$ to average values from the $\mathrm{X}$-ray diffraction analysis of $\left[\mathrm{Co}(\mathrm{CO})_{4}\left(\mathrm{H}_{7} \mathrm{Si}_{8} \mathrm{O}_{12}\right)\right]$. The numbering of the internal coordinates is shown in Figures 1 and 2. The torsion $\tau_{\mathrm{Si}-\mathrm{Co}}$ between the $\mathrm{Co}(\mathrm{CO})_{4}$ group and the siloxane cage was not included into the calculation, because it is expected below the detection limit and has hardly any influence on other vibrations. A description of the force fields of the other investigated molecules can be found in ref 34 . Molecular orbital calculations have been carried out with the modified QCPE1 $16^{35}$ program; see ref 36 .

\section{Results and Discussion}

Figures 3 and 4 show the IR and Raman spectra of the four investigated monosubstituted octahydrosilasesquioxanes. It was shown that the spectra of $\mathrm{RH}_{7} \mathrm{Si}_{8} \mathrm{O}_{12}\left(\mathrm{R}=\mathrm{Ph}, \mathrm{CH}=\mathrm{CHPh}, \mathrm{CH}_{2^{-}}\right.$ $\mathrm{CH}_{2} \mathrm{Ph}$ ) can be understood as superpositions of the vibrational structure of the substituent and the siloxane cage. ${ }^{29,30}$ Although complex spectra are expected because of the size and low symmetry of these molecules, most peaks can be assigned by spectral correlations with similar compounds. Yet, for a final assignment a normal coordinate analysis of all fundamentals was found to be necessary. The symmetry reduction was best described by treating the substituent as a point mass. This led to local $C_{3 v}$ symmetry for the siloxane cages. Peaks or splittings, which cannot be explained by this local symmetry, also occurred and were due to vibrational coupling with modes of the substituent.

\section{Vibrational Analysis of $\left[\mathrm{Co}(\mathrm{CO})_{4}\left(\mathrm{H}_{7} \mathrm{Si}_{8} \mathrm{O}_{12}\right)\right]$}

IR and Raman Spectra. This molecule has an ideal symmetry of $C_{3 v}$. X-ray diffraction has shown deviations for

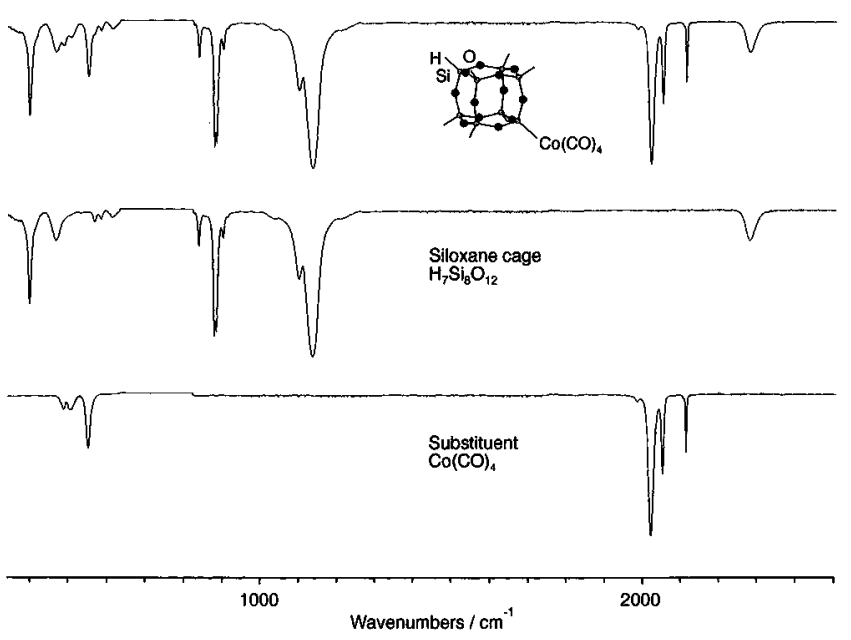

Figure 5. Transmission IR spectrum of $\left[\mathrm{Co}(\mathrm{CO})_{4}\left(\mathrm{H}_{7} \mathrm{Si}_{8} \mathrm{O}_{12}\right]\right.$ divided into the lines due to the siloxane cage and the substituent.
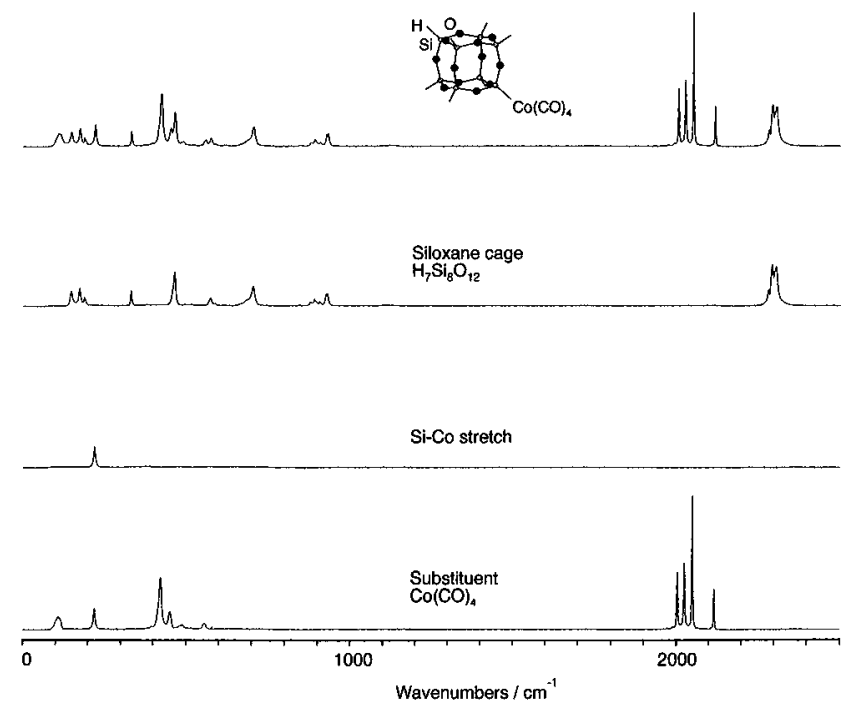

Figure 6. Fourier-transform Raman spectrum of $\left[\mathrm{Co}(\mathrm{CO})_{4}\left(\mathrm{H}_{7} \mathrm{Si}_{8} \mathrm{O}_{12}\right)\right]$ divided into the lines due to the siloxane cage, the substituent, and the $\mathrm{Si}-\mathrm{Co}$ stretch.

both the siloxane cage and the $\mathrm{Co}(\mathrm{CO})_{4}$ group. The $\mathrm{H}_{7} \mathrm{Si}_{8} \mathrm{O}_{12}$ fragment exhibits distortions around, and originating from, the $\mathrm{Si}$ atom to which the $\mathrm{Co}(\mathrm{CO})_{4}$ fragment binds. ${ }^{27}$

Figures 5 and 6 show the IR and Raman spectra divided into the contributions of the siloxane cage, the $\operatorname{Co}(\mathrm{CO})_{4}$ group, and the $\mathrm{Si}-\mathrm{Co}$ bond. This division was achieved by spectral correlations with $\left[\mathrm{Co}(\mathrm{CO})_{4}\left(\mathrm{SiX}_{3}\right)\right]$ compounds $(\mathrm{X}=\mathrm{H}, \mathrm{F}$, $\mathrm{Cl})^{33,37,38}$ and the normal coordinate analysis of the molecule. It can be seen that the $\mathrm{Co}(\mathrm{CO})_{4}$ fragment gives rise to very intense peaks. In the Raman spectrum of $\left[\mathrm{Co}(\mathrm{CO})_{4}\left(\mathrm{H}_{7} \mathrm{Si}_{8} \mathrm{O}_{12}\right)\right]$ they form the strongest lines, and in the IR spectrum they are of the same order of magnitude as the siloxane cage bands, which are also known to be responsible for very intense absorptions.

Above $800 \mathrm{~cm}^{-1}$ the spectra can be divided according to group frequencies into the following frequency regions: $\delta(\mathrm{O}-$ $\mathrm{Si}-\mathrm{H}), 850-950 \mathrm{~cm}^{-1} ; v_{\text {asym }}(\mathrm{Si}-\mathrm{O}-\mathrm{Si}), 1100-1200 \mathrm{~cm}^{-1}$; $v(\mathrm{C}-\mathrm{O}), 2000-2150 \mathrm{~cm}^{-1} ; v(\mathrm{Si}-\mathrm{H}),>2200 \mathrm{~cm}^{-1}$. As these regions do not overlap, an assignment to either siloxane cage or $\mathrm{Co}(\mathrm{CO})_{4}$ group vibrations is straightforward. Below 800 $\mathrm{cm}^{-1}$ the symmetrical $\mathrm{Si}-\mathrm{O}-\mathrm{Si}$ stretching $\left(750-550 \mathrm{~cm}^{-1}\right)$, the $\mathrm{O}-\mathrm{Si}-\mathrm{O}$ bending $\left(500-150 \mathrm{~cm}^{-1}\right)$, and the $\mathrm{Si}-\mathrm{O}-\mathrm{Si}$ bending vibrations $\left(<100 \mathrm{~cm}^{-1}\right)$ of the siloxane cage as well as the $\mathrm{CoC}$ stretching and $\mathrm{CoCO}$ deformation modes (650- 
TABLE 2: Definition of the Simplified General Valence Force Field for $\left[\mathrm{Co}(\mathrm{CO})_{4}\left(\mathrm{H}_{7} \mathrm{Si}_{8} \mathrm{O}_{12}\right)\right]$

\begin{tabular}{|c|c|c|c|c|c|c|c|c|c|c|c|c|c|c|c|c|c|c|c|c|c|c|c|c|}
\hline & $R_{1}$ & $r_{1}$ & $r_{2}$ & $r_{8}$ & $\alpha_{1}$ & $\alpha_{8}$ & $\beta_{1}$ & $\beta_{8}$ & $\phi$ & $D$ & $A$ & $S_{1}$ & $S_{2}$ & $T$ & $s_{1}$ & $s_{2}$ & $t$ & $\omega_{1}$ & $\epsilon_{1}$ & $\gamma_{1}$ & $\delta_{\text {out }_{1}}$ & $\delta_{\mathrm{out}_{2}}$ & $\delta_{\mathrm{in}_{1}}$ & $\delta_{\mathrm{ax}_{1}}$ \\
\hline$R_{1}$ & $f_{R}$ & & & & & & & & & & & & & & & & & & & & & & & \\
\hline$r_{1}$ & 0 & $f_{r}$ & & & & & & & & & & & & & & & & & & & & & & \\
\hline$r_{2}$ & 0 & $f_{r r}$ & $f_{r}$ & & & & & & & & & & & & & & & & & & & & & \\
\hline$r_{8}$ & 0 & $f_{r r}^{\prime \prime}$ & 0 & $f_{r}$ & & & & & & & & & & & & & & & & & & & & \\
\hline$\alpha_{1}$ & 0 & $f_{r \alpha}$ & 0 & $f_{r \alpha}^{\prime}$ & $f_{\alpha}$ & & & & & & & & & & & & & & & & & & & \\
\hline$\alpha_{8}$ & 0 & $f_{r \alpha}^{\prime}$ & 0 & $f_{r \alpha}$ & $f_{\alpha \alpha}$ & $f_{\alpha}$ & & & & & & & & & & & & & & & & & & \\
\hline$\beta_{1}$ & 0 & $f_{r \beta}$ & 0 & $f_{r \beta}^{\prime}$ & $f_{\alpha \beta}$ & $f_{\alpha \beta}^{\prime}$ & $f_{\beta}$ & & & & & & & & & & & & & & & & & \\
\hline$\beta_{8}$ & 0 & $f_{r \beta}^{\prime \prime}$ & 0 & $f_{r \beta}$ & $f_{\alpha \beta}^{\prime}$ & $f_{\alpha \beta}$ & $f_{\beta \beta}$ & $f_{\beta}$ & & & & & & & & & & & & & & & & \\
\hline$\phi$ & 0 & $f_{r \phi}$ & $f_{r \phi}$ & 0 & $f_{\alpha \phi}$ & 0 & $f_{\beta \phi}$ & 0 & $f_{\phi}$ & & & & & & & & & & & & & & & \\
\hline$D$ & 0 & 0 & 0 & 0 & 0 & 0 & 0 & 0 & 0 & $F_{D}$ & & & & & & & & & & & & & & \\
\hline$A$ & 0 & 0 & 0 & 0 & 0 & 0 & 0 & 0 & 0 & $F_{A D}$ & $F_{A}$ & & & & & & & & & & & & & \\
\hline$S_{1}$ & & & & & & & & & & 0 & 0 & $F_{S}$ & & & & & & & & & & & & \\
\hline$S_{2}$ & & & & & & & & & & 0 & 0 & $F_{S S}$ & $F_{S}$ & & & & & & & & & & & \\
\hline$T$ & & & & & & & & & & 0 & 0 & $F_{S T}$ & $F_{S T}$ & $F_{T}$ & & & & & & & & & & \\
\hline$s_{1}$ & & & & & & & & & & 0 & 0 & $F_{s S}$ & $F_{s S}^{\prime}$ & 0 & $F_{s}$ & & & & & & & & & \\
\hline$s_{2}$ & & & & & & & & & & 0 & 0 & $F_{s S}^{\prime}$ & $F_{S S}$ & 0 & $F_{s s}$ & $F_{s}$ & & & & & & & & \\
\hline$t$ & & & & & & & & & & 0 & 0 & 0 & 0 & $F_{t T}$ & $F_{s t}$ & $F_{s t}$ & $F_{t}$ & & & & & & & \\
\hline$\omega_{1}$ & & & & & & & & & & 0 & 0 & 0 & 0 & 0 & 0 & 0 & 0 & $F_{\omega}$ & & & & & & \\
\hline$\epsilon_{1}$ & & & & & & & & & & 0 & 0 & 0 & 0 & 0 & 0 & 0 & 0 & 0 & $F_{\epsilon}$ & & & & & \\
\hline$\gamma_{1}$ & & & & & & & & & & 0 & 0 & 0 & 0 & 0 & 0 & 0 & 0 & 0 & 0 & $F_{\gamma}$ & & & & \\
\hline$\delta_{\text {out }_{1}}$ & & & & & & & & & & 0 & 0 & 0 & 0 & $F_{T \delta_{\text {out }}}$ & 0 & 0 & 0 & 0 & 0 & 0 & $F_{\delta_{\text {out }}}$ & & & \\
\hline$\delta_{\text {out }_{2}}$ & & & & & & & & & & 0 & 0 & 0 & 0 & $F_{T \delta_{\text {out }}}$ & 0 & 0 & 0 & 0 & 0 & 0 & $F_{\delta \delta_{\text {out }}}$ & $F_{\delta_{\text {out }}}$ & & \\
\hline$\delta_{\mathrm{in}_{1}}$ & & & & & & & & & & 0 & 0 & 0 & 0 & 0 & 0 & 0 & 0 & 0 & 0 & 0 & & 0 & $F_{\delta_{\text {in }}}$ & \\
\hline$\delta_{\mathrm{ax}_{1}}$ & & & & & & & & & & 0 & 0 & 0 & $F_{S \delta_{\mathrm{ax}}}$ & 0 & 0 & 0 & 0 & 0 & 0 & 0 & 0 & 0 & 0 & $F_{\delta_{\mathrm{ax}}}$ \\
\hline
\end{tabular}

TABLE 3: Internal Force Constants for $\left[\mathrm{Co}(\mathrm{CO})_{4}\left(\mathrm{H}_{7} \mathrm{Si}_{8} \mathrm{O}_{12}\right)\right]$

\begin{tabular}{cccccc}
\hline $\begin{array}{c}\text { force } \\
\text { const }^{a}\end{array}$ & values & $\begin{array}{l}\text { force } \\
\text { const }^{a}\end{array}$ & values & $\begin{array}{l}\text { force } \\
\text { const }^{a}\end{array}$ & values \\
\hline$f_{R}$ & 2.96 & $f^{\prime}{ }_{r r}$ & 0.153 & $f_{\alpha \alpha}$ & 0 \\
$f_{r}$ & 5.10 & $f_{r \alpha} \mathrm{Si}_{8} \mathrm{O}_{12}$ & 0.188 & $f_{\beta \beta}$ & 0 \\
$f_{\alpha}$ & 0.601 & $f_{r \alpha}^{\prime}$ & 0 & $f_{\alpha \beta}$ & -0.095 \\
$f_{\beta}$ & 0.895 & $f_{r \beta}$ & -0.016 & $f_{\alpha \beta}^{\prime}$ & -0.175 \\
$f_{\phi}$ & 0.091 & $f^{\prime}{ }_{r \beta}$ & 0.144 & $f_{\alpha \phi}$ & 0.019 \\
$f_{r r}$ & 0.275 & $f_{r \phi}$ & 0.036 & $f_{\beta \phi}$ & 0.0026 \\
& & & $\mathrm{Co}(\mathrm{CO})_{4}$ & & \\
$F_{D}$ & 1.73 & $F_{\gamma}$ & 0.49 & $F_{s S}^{\prime}$ & 0.11 \\
$F_{A}$ & 0.57 & $F_{\delta_{\text {out }}}$ & 0.68 & $F_{s s}$ & 0.37 \\
$F_{S}$ & 2.41 & $F_{\delta_{\text {in }}}$ & 0.29 & $F_{t T}$ & 0.55 \\
$F_{T}$ & 2.25 & $F_{\delta_{\mathrm{ax}}}$ & 0.39 & $F_{s t}$ & 0.27 \\
$F_{s}$ & 16.64 & $F_{A D}$ & 0.25 & $F_{T \delta_{\text {out }}}$ & -0.08 \\
$F_{t}$ & 17.33 & $F_{S S}$ & 0.26 & $F_{\delta \delta_{\text {out }}}$ & -0.03 \\
$F_{\omega}$ & 0.38 & $F_{S T}$ & 0.13 & $F_{S \delta_{\text {ax }}}$ & 0.12 \\
$F_{\epsilon}$ & 0.51 & $F_{s S}$ & 0.55 & &
\end{tabular}

${ }^{a}$ Force constants units: stretching constants, mdyn/Å; bending constants, mdyn $\AA / \mathrm{rad}^{2}$; stretch bend interactions, mdyn/rad.

$\left.300 \mathrm{~cm}^{-1}\right)$ of the $\mathrm{Co}(\mathrm{CO})_{4}$ group occur. For a final assignment a normal coordinate analysis was therefore carried out.

Force Field. The modified general valence force field of $\left[\mathrm{Co}(\mathrm{CO})_{4}\left(\mathrm{H}_{7} \mathrm{Si}_{8} \mathrm{O}_{12}\right)\right]$ is defined in Table 2, and the force constant values are given in Table 3 . For the siloxane cage the same force constant definitions and values were used as for $\mathrm{H}_{8}$ $\mathrm{Si}_{8} \mathrm{O}_{12}$. Additional force constants were introduced for the part involving the $\mathrm{Si}-\mathrm{Co}$ bond. The definitions for the $\mathrm{Co}(\mathrm{CO})_{4}$ group are based on the ones of ref 33 . The values were determined by a fit to the IR and Raman frequencies of [Co$\left.(\mathrm{CO})_{4}\left(\mathrm{H}_{7} \mathrm{Si}_{8} \mathrm{O}_{12}\right)\right]$ using the force constants of $\left[\mathrm{Co}(\mathrm{CO})_{4}\left(\mathrm{SiCl}_{3}\right)\right]$ as starting values. The calculated frequencies are listed and compared with the experimental ones in Table 4. The assignment to symmetry types assuming an idealized $C_{3 v}$ symmetry and the correlation with the symmetry species of $O_{h}-\mathrm{H}_{8} \mathrm{Si}_{8} \mathrm{O}_{12}$ is also given in this table.

Table 2 shows that it is possible to describe $\left[\mathrm{Co}(\mathrm{CO})_{4}\left(\mathrm{H}_{7-}\right.\right.$ $\left.\mathrm{Si}_{8} \mathrm{O}_{12}\right)$ ] with a relatively restricted number of interaction force constants. Particularly those between the three parts, siloxane cage, $\mathrm{Si}-\mathrm{Co}$ bond, and $\mathrm{Co}(\mathrm{CO})_{4}$ group, can be neglected. This confirms the notion of $\left[\mathrm{Co}(\mathrm{CO})_{4}\left(\mathrm{H}_{7} \mathrm{Si}_{8} \mathrm{O}_{12}\right)\right]$ as being composed

of relatively independently vibrating moieties. The finally obtained force constants led to a good agreement of the calculated and measured frequencies as shown in Table 4. All peaks could be assigned to either vibrations of the substituent or the siloxane cage with one exception: the two vibrations at 461 and $449 \mathrm{~cm}^{-1}$ in the Raman spectrum both show similar contributions of axial $\mathrm{CoC}$ stretching and $\mathrm{O}-\mathrm{Si}-\mathrm{O}$ bending movements.

CO Stretching Vibrations. The CO stretching vibrations, which are situated at ca. $2000 \mathrm{~cm}^{-1}$, have been investigated thoroughly for different metal carbonyl compounds. ${ }^{39-42}$ Assuming $C_{3 v}$ symmetry for the $\operatorname{Co}(\mathrm{CO})_{4}$ fragment, they form an $\mathrm{E}$ and two $\mathrm{A}_{1}$ type vibrations. The similar intensities of the two $A_{1}$ modes exhibited in the IR spectra of different metal carbonyl compounds led to the conclusion that the equatorial and the axial $\mathrm{A}_{1} \mathrm{CO}$ stretching movements are coupled. This was also confirmed by the depolarization ratio observed in the Raman spectra of $\left[\mathrm{Co}(\mathrm{CO})_{4}\left(\mathrm{SiCl}_{3}\right)\right],\left[\mathrm{Co}(\mathrm{CO})_{4}\left(\mathrm{GeCl}_{3}\right)\right]$, and [Co$\left.(\mathrm{CO})_{4}\left(\mathrm{GeBr}_{3}\right)\right]$ in solution. ${ }^{37,42}$ The vibration of $\left[\mathrm{Co}(\mathrm{CO})_{4}\left(\mathrm{H}_{7^{-}}\right.\right.$ $\mathrm{Si}_{8} \mathrm{O}_{12}$ )] at 2111 (IR)/2110 $\mathrm{cm}^{-1}$ (Raman) forms therefore the in-phase and the one at 2050 (IR)/2044 (Raman) $\mathrm{cm}^{-1}$ the outof-phase combination of the axial and equatorial $\mathrm{CO}$ stretching coordinates.

$\mathrm{Si}-\mathrm{Co}$ Stretching Vibration. The $\mathrm{Si}-\mathrm{Co}$ stretching vibration is assigned to the sharp Raman peak of medium intensity at $220 \mathrm{~cm}^{-1}$, which exhibits $33 \% \mathrm{Si}-\mathrm{Co}$ stretching character in the potential energy distribution. The vibration at $329 \mathrm{~cm}^{-1}$ also showed considerable $\mathrm{Si}-\mathrm{Co}$ stretching character (15\%). $\mathrm{Si}-\mathrm{Co}$ stretching vibrations of similar compounds are located at $318 \mathrm{~cm}^{-1}\left(\left[\mathrm{Co}(\mathrm{CO})_{4}\left(\mathrm{SiH}_{3}\right)\right]\right), 307 \mathrm{~cm}^{-1}\left(\left[\mathrm{Co}(\mathrm{CO})_{4}\left(\mathrm{SiCl}_{3}\right)\right]\right)$, and $246 \mathrm{~cm}^{-1}\left(\left[\mathrm{Co}(\mathrm{CO})_{4}\left(\mathrm{SiF}_{3}\right)\right]\right)$. The $\mathrm{O}-\mathrm{Si}-\mathrm{Co}$ bending vibration was below the detection limit.

The siloxane cage vibrations show a similar pattern as in other monosubstituted octahydrosilasesquioxanes and will therefore be discussed in the next section together with the siloxane cage spectra of the other investigated compounds.

\section{Siloxane Cage Vibrations of Monosubstituted Octahydrosilasesquioxanes}

A comparison of the siloxane cage vibrations of the $\mathrm{RH}_{7}$ $\mathrm{Si}_{8} \mathrm{O}_{12}$ molecules $\left(\mathrm{R}=\mathrm{Co}(\mathrm{CO})_{4}, \mathrm{Ph}, \mathrm{CH}=\mathrm{CHPh}, \mathrm{CH}_{2} \mathrm{CH}_{2} \mathrm{Ph}\right.$, 
TABLE 4: Observed and Calculated Frequencies for $\left[\mathrm{Co}(\mathrm{CO})_{4}\left(\mathrm{H}_{7} \mathrm{Si}_{8} \mathrm{O}_{12}\right)\right](v=$ Stretch, $\delta=$ Bending $)$

\begin{tabular}{|c|c|c|c|c|c|}
\hline \multicolumn{2}{|c|}{$\begin{array}{l}\text { symmetry } \\
\text { type }\end{array}$} & \multicolumn{3}{|c|}{ wavenumber/cm ${ }^{-1}$} & \multirow[b]{2}{*}{ vibration type } \\
\hline$O_{h}$ & $C_{3 v}$ & IR & Raman & calc & \\
\hline$A_{1 g}$ & $\mathrm{~A}_{1}$ & & 2297 & 2275 & $v(\mathrm{Si}-\mathrm{H})$ \\
\hline$T_{2 g}$ & $\mathrm{E}, \mathrm{A}_{1}$ & & $2301 / 2292,2285$ & 2275,2275 & $v(\mathrm{Si}-\mathrm{H})$ \\
\hline $\mathrm{T}_{1 \mathrm{u}}$ & $\mathrm{A}_{1}, \mathrm{E}$ & 2276,2276 & 2285,2274 & 2275,2275 & $v(\mathrm{Si}-\mathrm{H})$ \\
\hline & $\mathrm{A}_{1}$ & 2111 & 2110 & 2111 & $v(\mathrm{CO})$ \\
\hline & $\mathrm{A}_{1}$ & 2050 & 2044 & 2046 & $v(\mathrm{CO})$ \\
\hline & $\mathrm{E}$ & 2021 & $2020 / 1998$ & 2020 & $v(\mathrm{CO})$ \\
\hline & & 1984 & & & $v\left({ }^{13} \mathrm{CO}\right)$ \\
\hline $\mathrm{T}_{1 \mathrm{~g}}$ & $\mathrm{E}, \mathrm{A}_{2}$ & & & 1161,1161 & $\delta_{\text {asym }}(\mathrm{Si}-\mathrm{O}-\mathrm{Si})$ \\
\hline $\mathrm{E}_{\mathrm{u}}$ & $\mathrm{E}$ & & & 1159 & $\delta_{\text {asym }}(\mathrm{Si}-\mathrm{O}-\mathrm{Si})$ \\
\hline $\mathrm{T}_{1 \mathrm{u}}$ & $\mathrm{E}, \mathrm{A}_{1}$ & 1138,1138 & & 1143,1143 & $\delta_{\text {asym }}(\mathrm{Si}-\mathrm{O}-\mathrm{Si})$ \\
\hline $\mathrm{T}_{2 \mathrm{~g}}$ & $\mathrm{~A}_{1}, \mathrm{E}$ & 1101 & $\sim 1117, \sim 1117$ & 1117,1116 & $\delta_{\text {asym }}(\mathrm{Si}-\mathrm{O}-\mathrm{Si})$ \\
\hline $\mathrm{A}_{2 \mathrm{u}}$ & $\mathrm{A}_{1}$ & & & 1083 & $\delta_{\text {asym }}(\mathrm{Si}-\mathrm{O}-\mathrm{Si})$ \\
\hline $\mathrm{E}_{\mathrm{g}}$ & $\mathrm{E}$ & 916 & $928 / 923$ & 921 & $\delta(\mathrm{O}-\mathrm{Si}-\mathrm{H})$ \\
\hline $\mathrm{T}_{2 \mathrm{u}}$ & $\mathrm{A}_{2}, \mathrm{E}$ &,- 904 &,- 904 & 918,910 & $\delta(\mathrm{O}-\mathrm{Si}-\mathrm{H})$ \\
\hline $\mathrm{T}_{2 \mathrm{~g}}$ & $\mathrm{~A}_{1}, \mathrm{E}$ &,- 886 & 893,888 & 894,889 & $\delta(\mathrm{O}-\mathrm{Si}-\mathrm{H})$ \\
\hline $\mathrm{T}_{1 \mathrm{u}}$ & $\mathrm{A}_{1}, \mathrm{E}$ & 886,881 & 878,875 & 882,874 & $\delta(\mathrm{O}-\mathrm{Si}-\mathrm{H})$ \\
\hline $\mathrm{T}_{1 \mathrm{~g}}$ & $\mathrm{~A}_{2}, \mathrm{E}$ & 857,840 &,- 841 & 865,864 & $\delta(\mathrm{O}-\mathrm{Si}-\mathrm{H})$ \\
\hline $\mathrm{E}_{\mathrm{g}}{ }^{\circ}$ & $\mathrm{E}$ & & 701 & 714 & $v_{\mathrm{sym}}(\mathrm{Si}-\mathrm{O}-\mathrm{Si})$ \\
\hline $\mathrm{T}_{2 \mathrm{u}}$ & $\mathrm{E}, \mathrm{A}_{2}$ & & 684 & 687,682 & $v_{\mathrm{sym}}(\mathrm{Si}-\mathrm{O}-\mathrm{Si})$ \\
\hline $\mathrm{T}_{2 \mathrm{~g}}$ & $\mathrm{~A}_{1}, \mathrm{E}$ & 613 & $\sim 616$ & 625,621 & $v_{\text {sym }}(\mathrm{Si}-\mathrm{O}-\mathrm{Si})$ \\
\hline $\mathrm{T}_{1 \mathrm{u}}$ & $\mathrm{A}_{1}, \mathrm{E}$ & 584,565 & $585,-$ & 586,572 & $v_{\text {sym }}(\mathrm{O}-\mathrm{Si}-\mathrm{O})$ \\
\hline$A_{1 g}$ & $\mathrm{~A}_{1}$ & & 571 & 575 & $\delta(\mathrm{O}-\mathrm{Si}-\mathrm{O})$ \\
\hline & $\mathrm{E}$ & 552 & 554 & 557 & $\delta(\mathrm{CoCO})_{\text {out }}$ \\
\hline & $\mathrm{A}_{1}$ & 552 & 554 & 553 & $\delta(\mathrm{CoCO})_{\text {out }}$ \\
\hline & $\mathrm{E}$ & 507 & & 504 & $\begin{array}{l}v(\mathrm{CoC})_{\mathrm{eq}}^{+} \\
\quad \delta(\mathrm{CoCO})_{\mathrm{ax}}\end{array}$ \\
\hline & $\mathrm{E}$ & 488 & 487 & 490 & $\begin{array}{c}\delta(\mathrm{CoCO})_{\mathrm{ax}}+ \\
\mathrm{v}(\mathrm{CoC})_{\mathrm{eq}}\end{array}$ \\
\hline $\mathrm{T}_{1 \mathrm{u}}$ & $\mathrm{E}, \mathrm{A}_{1}$ & 469,469 & & 487,480 & $v_{\text {sym }}(\mathrm{O}-\mathrm{Si}-\mathrm{O})$ \\
\hline$A_{1 g}$ & $\mathrm{~A}_{1}$ & & 461 & 468 & $\begin{array}{c}v_{\mathrm{sym}}(\mathrm{O}-\mathrm{Si}-\mathrm{O})+ \\
v(\mathrm{CoC})_{\mathrm{ax}}\end{array}$ \\
\hline & $\mathrm{A}_{1}$ & & 449 & 445 & $\begin{array}{l}v(\mathrm{CoC})_{\mathrm{ax}}+ \\
\quad v_{\mathrm{sym}}(\mathrm{O}-\mathrm{Si}-\mathrm{O})\end{array}$ \\
\hline $\mathrm{T}_{2 \mathrm{~g}}$ & $\mathrm{E}, \mathrm{A}_{1}$ & & & 426,417 & $\delta(\mathrm{O}-\mathrm{Si}-\mathrm{O})$ \\
\hline $\mathrm{E}_{\mathrm{g}}$ & $\mathrm{E}$ & & & 422 & $\delta(\mathrm{O}-\mathrm{Si}-\mathrm{O})$ \\
\hline & $\mathrm{A}_{1}$ & & 420 & 421 & $v(\mathrm{CoC})_{\mathrm{eq}}$ \\
\hline $\mathrm{T}_{1 \mathrm{u}}$ & $\mathrm{A}_{1}, \mathrm{E}$ & 399,399 & & 402,398 & $\delta(\mathrm{O}-\mathrm{Si}-\mathrm{O})$ \\
\hline & $\mathrm{E}$ & & 393 & 393 & $\delta(\mathrm{CoCO})_{\mathrm{in}}$ \\
\hline $\mathrm{T}_{1 \mathrm{~g}}$ & $\mathrm{E}, \mathrm{A}_{2}$ & & & 360,356 & $\delta(\mathrm{O}-\mathrm{Si}-\mathrm{O})$ \\
\hline & $\mathrm{A}_{2}$ & & & 331 & $\delta(\mathrm{CoCO})_{\mathrm{in}}$ \\
\hline $\mathrm{A}_{2 \mathrm{u}}$ & $\mathrm{A}_{1}$ & & 329 & 316 & $\delta(\mathrm{O}-\mathrm{Si}-\mathrm{O})$ \\
\hline $\mathrm{T}_{2 \mathrm{u}}$ & $\mathrm{E}, \mathrm{A}_{2}$ & & & 305,303 & $\delta(\mathrm{O}-\mathrm{Si}-\mathrm{O})$ \\
\hline $\mathrm{A}_{2 \mathrm{u}}$ & $\mathrm{A}_{1}$ & & 220 & 219 & $v(\mathrm{Si}-\mathrm{Co})$ \\
\hline $\mathrm{E}_{\mathrm{u}}$ & $\mathrm{E}$ & & $190 / 187$ & 183 & $\delta(\mathrm{O}-\mathrm{Si}-\mathrm{O})$ \\
\hline $\mathrm{T}_{2 \mathrm{~g}}$ & $\mathrm{E}, \mathrm{A}_{1}$ & & 173,147 & 168,144 & $\delta(\mathrm{O}-\mathrm{Si}-\mathrm{O})$ \\
\hline & $\mathrm{E}$ & & 115 & 122 & $\delta(\mathrm{CCoC})$ \\
\hline & $\mathrm{E}$ & & 109 & 109 & $\delta(\mathrm{CCoC})$ \\
\hline $\mathrm{E}_{\mathrm{u}}$ & $\mathrm{E}$ & & & 100 & $\begin{array}{c}\delta(\mathrm{Si}-\mathrm{O}-\mathrm{Si})+ \\
\delta(\mathrm{OSiCo})\end{array}$ \\
\hline & $\mathrm{A}_{1}$ & & & 82 & $\delta(\mathrm{CCoC})$ \\
\hline $\mathrm{E}_{\mathrm{g}}$ & $\mathrm{E}$ & & & 77 & $\delta(\mathrm{Si}-\mathrm{O}-\mathrm{Si})$ \\
\hline $\mathrm{T}_{2 \mathrm{u}}$ & $\mathrm{E}, \mathrm{A}_{2}$ & & & 70,68 & $\begin{array}{c}\delta(\mathrm{Si}-\mathrm{O}-\mathrm{Si})+ \\
\delta(\mathrm{SiCoC})\end{array}$ \\
\hline & $\mathrm{E}$ & & & 30 & $\begin{array}{c}\delta(\mathrm{SiCoC})+ \\
\delta(\mathrm{OSiCo})\end{array}$ \\
\hline
\end{tabular}

and $\mathrm{C}_{6} \mathrm{H}_{13}$ (only IR)), and $\mathrm{H}_{8} \mathrm{Si}_{8} \mathrm{O}_{12}$ is given in Table 5 for the IR and in Table 6 for the Raman spectra. Compared with $\mathrm{H}_{8^{-}}$ $\mathrm{Si}_{8} \mathrm{O}_{12}$ no large frequency shifts are observed. It can be seen that the introduction of a substituent gives rise to additional peaks and peak splittings. The influence of the substituent will be discussed below in detail.

Si-H Stretching Vibrations $\left(2200-2300 \mathbf{c m}^{-1}\right)$. This region consists in the IR spectra of all monosubstituted compounds of one absorption, which exhibits a slight broadening due to the substituent ( $\mathrm{fwhh}=28-30 \mathrm{~cm}^{-1}$ compared with 26 $\mathrm{cm}^{-1}$ in $\mathrm{H}_{8} \mathrm{Si}_{8} \mathrm{O}_{12}$ ).

In the Raman spectra the $\mathrm{Si}-\mathrm{H}$ stretching region is less uniform. The number of peaks and shoulders varies from two for $\left(\mathrm{PhCH}_{2} \mathrm{CH}_{2}\right) \mathrm{H}_{7} \mathrm{Si}_{8} \mathrm{O}_{12}$ to six for $\left[\mathrm{Co}(\mathrm{CO})_{4}\left(\mathrm{H}_{7} \mathrm{Si}_{8} \mathrm{O}_{12}\right)\right]$. The considered $\mathrm{RH}_{7} \mathrm{Si}_{8} \mathrm{O}_{12}$ molecules show a shift of $5-11 \mathrm{~cm}^{-1}$ to lower energy for the totally symmetric peak (at $2302 \mathrm{~cm}^{-1}$ in $\left.\mathrm{H}_{8} \mathrm{Si}_{8} \mathrm{O}_{12}\right)$. The $\mathrm{T}_{2 \mathrm{~g}} v(\mathrm{Si}-\mathrm{H})$ of $\mathrm{H}_{8} \mathrm{Si}_{8} \mathrm{O}_{12}$ exhibits in the Raman spectrum of the solid a splitting of $10 \mathrm{~cm}^{-1}$ due to the symmetry reduction to $S_{6}$ in the crystal. In the case of an organic substituent this splitting is reduced. This is in accordance with the X-ray diffractions of $\left(\mathrm{C}_{6} \mathrm{H}_{13}\right) \mathrm{H}_{7} \mathrm{Si}_{8} \mathrm{O}_{12}$, and $\mathrm{PhH}_{7} \mathrm{Si}_{8} \mathrm{O}_{12}$, which indicate rather smaller distorsions of the siloxane cage for these molecules than for $\mathrm{H}_{8} \mathrm{Si}_{8} \mathrm{O}_{12}$. It cannot be decided whether the splittings in the monosubstituted compounds are due to interactions in the crystal or to the influence of the substituent. The Raman spectrum of $\left[\mathrm{Co}(\mathrm{CO})_{4}\left(\mathrm{H}_{7} \mathrm{Si}_{8} \mathrm{O}_{12}\right)\right]$ is rather complex in this region, so that a definite assignment is difficult. The one given in Table 6 can be considered as the most probable. The $\mathrm{Si}-\mathrm{H}$ stretching regions are, with the exception of the one of $\left[\mathrm{Co}(\mathrm{CO})_{4}\left(\mathrm{H}_{7} \mathrm{Si}_{8} \mathrm{O}_{12}\right)\right]$, in accordance with a local $C_{3 v}$ symmetry for the siloxane cage.

Antisymmetrical Si-O-Si Stretching Vibrations (1100$\left.1200 \mathbf{c m}^{-1}\right)$. The IR spectrum of $\mathrm{H}_{8} \mathrm{Si}_{8} \mathrm{O}_{12}$ consists in this region of one intense broad band. The full width at half-height increases from $27 \mathrm{~cm}^{-1}$ in $\mathrm{H}_{8} \mathrm{Si}_{8} \mathrm{O}_{12}$ to $33-38 \mathrm{~cm}^{-1}$ in the monosubstituted molecules. As the only compound, $\left[\mathrm{Co}(\mathrm{CO})_{4}\left(\mathrm{H}_{7^{-}}\right.\right.$ $\left.\mathrm{Si}_{8} \mathrm{O}_{12}\right)$ ] shows a shoulder at $1101 \mathrm{~cm}^{-1}$ which can be correlated with the $\mathrm{T}_{2 \mathrm{~g}} v_{\text {asym }}(\mathrm{Si}-\mathrm{O}-\mathrm{Si})$ stretching mode. The anitsymmetrical $\mathrm{Si}-\mathrm{O}-\mathrm{Si}$ stretching vibrations appear as broad weak features in the Raman spectra of the monosubstituted molecules. Their maxima correlate well with the one of the Raman active $\mathrm{T}_{2 \mathrm{~g}} \nu_{\text {asym }}(\mathrm{Si}-\mathrm{O}-\mathrm{Si})$ of $\mathrm{H}_{8} \mathrm{Si}_{8} \mathrm{O}_{12}$. Only $\mathrm{PhH}_{7} \mathrm{Si}_{8} \mathrm{O}_{12}$ shows two distinct peaks in this region. This is in accordance with the normal coordinate analysis, which predicts a splitting of the $T_{2 g}$ $v_{\text {asym }}(\mathrm{Si}-\mathrm{O}-\mathrm{Si})$ in the case of $\mathrm{R}=\mathrm{Ph}$, due to mixing with vibrations of the phenyl substituent $(\nu(\mathrm{C}-\mathrm{C}), \delta(\mathrm{C}-\mathrm{H}))$.

O-Si-H Bending Vibrations $\left(800-950 \mathbf{c m}^{-1}\right)$. This region shows a typical pattern for monosubstituted octahydrosilasesquioxanes. Assuming $C_{3 v}$ symmetry, nine modes are expected, seven IR- and Raman-active $\left(2 \mathrm{~A}_{1}, 5 \mathrm{E}\right)$ and two inactive ones $\left(2 \mathrm{~A}_{2}\right)$. The intense doublet at ca. $885 \mathrm{~cm}^{-1}$ in the IR spectra can be correlated with the IR-active $\mathrm{T}_{1 \mathrm{u}}$ and the Raman-active $\mathrm{T}_{2 \mathrm{~g}} \delta(\mathrm{O}-\mathrm{Si}-\mathrm{H})$ of $\mathrm{H}_{8} \mathrm{Si}_{8} \mathrm{O}_{12}$. The peak at ca. $850 \mathrm{~cm}^{-1}$ correlates with the inactive $\mathrm{T}_{1 \mathrm{~g}} \delta(\mathrm{O}-\mathrm{Si}-\mathrm{H})$ of $\mathrm{H}_{8^{-}}$ $\mathrm{Si}_{8} \mathrm{O}_{12}$. It appears in several monosubstituted compounds as a doublet, which is not in agreement with a local $C_{3 v}$ symmetry.

The Raman spectra of the monosubstituted compounds show seven to eight features in this region, some of them corresponding to a lower symmetry than $C_{3 v}$. Only $\mathrm{PhH}_{7} \mathrm{Si}_{8} \mathrm{O}_{12}$ is fully compatible with a local $C_{3 v}$ symmetry.

Vibrations of the Framework between 800 and $500 \mathrm{~cm}^{-1}$. This region consists for $O_{h}-\mathrm{H}_{8} \mathrm{Si}_{8} \mathrm{O}_{12}$ of five modes: one is IR $\left(T_{1 \mathrm{u}}\right)$, three are Raman $\left(\mathrm{E}_{\mathrm{g}}, \mathrm{T}_{2 \mathrm{~g}}, \mathrm{~A}_{1 \mathrm{~g}}\right)$, and one is inactive $\left(\mathrm{T}_{2 \mathrm{u}}\right)$. The IR spectra of the monosubstituted hydrosilasesquioxanes show rather weak absorptions with intensities that are dependent on the specific substituents. The Raman spectra exhibit in all investigated $\mathrm{RH}_{7} \mathrm{Si}_{8} \mathrm{O}_{12}$ compounds three peaks. The $\mathrm{A}_{1 \mathrm{~g}} \delta(\mathrm{O}-$ $\mathrm{Si}-\mathrm{O})$ appears at $580 \mathrm{~cm}^{-1}$ in $\mathrm{H}_{8} \mathrm{Si}_{8} \mathrm{O}_{12}$ and shows small frequency shifts depending on the specific substituents. The inactive $\mathrm{T}_{2 \mathrm{u}} v_{\text {sym }}(\mathrm{Si}-\mathrm{O}-\mathrm{Si})$ forms in all monosubstituted compounds a band of medium intensity between 680 and 690 $\mathrm{cm}^{-1}$. The $\mathrm{E}_{\mathrm{g}} v_{\text {sym }}(\mathrm{Si}-\mathrm{O}-\mathrm{Si})$ at $697 \mathrm{~cm}^{-1}$ in $\mathrm{H}_{8} \mathrm{Si}_{8} \mathrm{O}_{12}$ shows splittings of different size depending on the substituent. These splittings were predicted by the normal coordinate analysis and are due to coupling effects. For $\mathrm{RH}_{7} \mathrm{Si}_{8} \mathrm{O}_{12}(\mathrm{R}=\mathrm{Ph}, \mathrm{CH}=\mathrm{CHPh}$, and $\left.\mathrm{CH}_{2} \mathrm{CH}_{2} \mathrm{Ph}\right)$, the $\mathrm{T}_{2 \mathrm{~g}} v_{\mathrm{sym}}(\mathrm{Si}-\mathrm{O}-\mathrm{Si})$ at $610 \mathrm{~cm}^{-1}$ in $\mathrm{H}_{8^{-}}$ $\mathrm{Si}_{8} \mathrm{O}_{12}$ is hidden behind the $\delta(\mathrm{C}-\mathrm{C})$ mode at ca. $620 \mathrm{~cm}^{-1}$ of the phenyl ring. For $\mathrm{R}=\mathrm{CH}=\mathrm{CHPh}$ this mode shows a larger splitting, and the $\mathrm{A}_{1}$ component could be observed. 
TABLE 5: IR Frequencies of the Siloxane Cage Vibrations of Different Monosubstituted Octahydrosilasesquioxanes, $\mathrm{RH}_{7} \mathrm{Si}_{8} \mathrm{O}_{12}$, and the Unsubstituted Compound $(\mathrm{R}=\mathbf{H})$

\begin{tabular}{|c|c|c|c|c|c|c|c|c|}
\hline \multicolumn{6}{|c|}{ wavenumber $/ \mathrm{cm}^{-1}$} & \multicolumn{2}{|c|}{ symmetry } & \multirow[b]{2}{*}{ vibration type } \\
\hline $\mathrm{R}=\mathrm{Co}(\mathrm{CO})_{4}$ & $\mathrm{R}=\mathrm{Ph}$ & $\mathrm{R}=\mathrm{CH}=\mathrm{CHPh}$ & $\mathrm{R}=\mathrm{CH}_{2} \mathrm{CH}_{2} \mathrm{Ph}$ & $\mathrm{R}=\mathrm{C}_{6} \mathrm{H}_{13}$ & $\mathrm{R}=\mathrm{H}$ & $C_{3 v}$ & $O_{h}$ & \\
\hline 2276,2276 & 2274,2274 & 2275,2275 & 2274,2274 & 2274 & 2277 & $\mathrm{~A}_{1}, \mathrm{E}$ & $\mathrm{T}_{1 \mathrm{u}}$ & $v(\mathrm{Si}-\mathrm{H})$ \\
\hline 1138,1138 & 1140,1140 & 1140,1140 & 1141,1141 & 1139 & 1141 & $\mathrm{~A}_{1}, \mathrm{E}$ & $\mathrm{T}_{1 \mathrm{u}}$ & $\nu_{\text {asym }}(\mathrm{Si}-\mathrm{O}-\mathrm{Si})$ \\
\hline 1101 & & & & & & $\mathrm{~A}_{1}, \mathrm{E}$ & $\mathrm{T}_{2 \mathrm{~g}}$ & $\nu_{\text {asym }}(\mathrm{Si}-\mathrm{O}-\mathrm{Si})$ \\
\hline 916 & 915 & 915 & 916 & 916 & & $\mathrm{E}$ & $\mathrm{E}_{\mathrm{g}}$ & $\delta(\mathrm{O}-\mathrm{Si}-\mathrm{H})$ \\
\hline,- 904 &,- 905 &,- 905 &,- 905 &,- 905 & & $\mathrm{~A}_{2}, \mathrm{E}$ & $\mathrm{T}_{2 \mathrm{u}}$ & $\delta(\mathrm{O}-\mathrm{Si}-\mathrm{H})$ \\
\hline,- 886 &,- 886 &,- 886 &,- 886 &,- 887 & & $A_{1}, E$ & $\mathrm{~T}_{2 \mathrm{~g}}$ & $\delta(\mathrm{O}-\mathrm{Si}-\mathrm{H})$ \\
\hline 886,881 & 886,881 & 886,883 & 886,882 & 887,882 & 881 & $A_{1}, E$ & $\mathrm{~T}_{1 \mathrm{u}}$ & $\delta(\mathrm{O}-\mathrm{Si}-\mathrm{H})$ \\
\hline 857,840 &,- 844 & 854,848 & 852,846 &,- 846 & & $\mathrm{~A}_{2}, \mathrm{E}$ & $\mathrm{T}_{1 \mathrm{~g}}$ & $\delta(\mathrm{O}-\mathrm{Si}-\mathrm{H})$ \\
\hline & $718 / 704$ & & & & & $\mathrm{E}$ & $\mathrm{E}_{\mathrm{g}}$ & $v_{\text {sym }}(\mathrm{Si}-\mathrm{O}-\mathrm{Si})$ \\
\hline 613 & & & $607,622 / 18$ & & & $\mathrm{~A}_{1}, \mathrm{E}$ & $\mathrm{T}_{2 \mathrm{~g}}$ & $v_{\text {sym }}(\mathrm{Si}-\mathrm{O}-\mathrm{Si})$ \\
\hline & & & 573 & 572 & & $\mathrm{~A}_{1}$ & $A_{1 g}$ & $\delta(\mathrm{O}-\mathrm{Si}-\mathrm{O})$ \\
\hline 584,565 &,- 568 & &,- 568 & & 566 & $\mathrm{~A}_{1}, \mathrm{E}$ & $\mathrm{T}_{1 \mathrm{u}}$ & $v_{\mathrm{sym}}(\mathrm{O}-\mathrm{Si}-\mathrm{O})$ \\
\hline 469,469 & 475,475 & 469,469 & 468,468 & 468 & 465 & $\mathrm{~A}_{1}, \mathrm{E}$ & $\mathrm{T}_{1 \mathrm{u}}$ & $v_{\mathrm{sym}}(\mathrm{O}-\mathrm{Si}-\mathrm{O})$ \\
\hline 399,399 & 401,401 & 402,388 & 395,402 & 401 & 399 & $\mathrm{~A}_{1}, \mathrm{E}$ & $\mathrm{T}_{1 \mathrm{u}}$ & $\delta(\mathrm{O}-\mathrm{Si}-\mathrm{O})$ \\
\hline
\end{tabular}

TABLE 6: Raman Frequencies of the Siloxane Cage Vibrations of Different Monosubstituted Octahydrosilasesquioxanes $\mathrm{RH}_{7} \mathrm{Si}_{8} \mathrm{O}_{12}$ and the Unsubstituted Compound $(\mathrm{R}=\mathbf{H})$

\begin{tabular}{|c|c|c|c|c|c|c|c|}
\hline \multicolumn{4}{|c|}{ wavenumber $/ \mathrm{cm}^{-1}$} & \multicolumn{2}{|c|}{ symmetry } & \multirow[b]{2}{*}{$\mathrm{H}_{8} \mathrm{Si}_{8} \mathrm{O}_{12}$} & \multirow[b]{2}{*}{ vibration type } \\
\hline $\mathrm{R}=\mathrm{Co}(\mathrm{CO})_{4}$ & $\mathrm{R}=\mathrm{Ph}$ & $\mathrm{R}=\mathrm{CH}=\mathrm{CHPh}$ & $\mathrm{R}=\mathrm{CH}_{2} \mathrm{CH}_{2} \mathrm{Ph}$ & $C_{3 v}$ & $O_{h}$ & & \\
\hline 2297 & 2291 & 2295 & 2295 & $\mathrm{~A}_{1}, \mathrm{E}$ & $\mathrm{A}_{1 \mathrm{~g}}$ & 2302 & $v(\mathrm{Si}-\mathrm{H})$ \\
\hline $2285,2301 / 2292$ & 2278,2285 & 2284,2278 & 2286,2286 & $\mathrm{~A}_{1}, \mathrm{E}$ & $\mathrm{T}_{2 \mathrm{~g}}$ & 2296,2286 & $v(\mathrm{Si}-\mathrm{H})$ \\
\hline 2285,2274 & 2269,2275 & & & $\mathrm{~A}_{1}, \mathrm{E}$ & $\mathrm{T}_{1 \mathrm{u}}$ & & $v(\mathrm{Si}-\mathrm{H})$ \\
\hline$\sim 1117, \sim 1117$ & 1140,1121 & 1119,1119 & 1118,1118 & $\mathrm{~A}_{1}, \mathrm{E}$ & $\mathrm{T}_{2 \mathrm{~g}}$ & 1117 & $\nu_{\text {asym }}(\mathrm{Si}-\mathrm{O}-\mathrm{Si})$ \\
\hline $928 / 923$ & 925 & 927 & $928 / 26$ & $\mathrm{E}$ & $\mathrm{E}_{\mathrm{g}}$ & 932 & $\delta(\mathrm{O}-\mathrm{Si}-\mathrm{H})$ \\
\hline,- 904 &,- 904 &,- 900 &,- 899 & $\mathrm{~A}_{2}, \mathrm{E}$ & $\mathrm{T}_{2 \mathrm{u}}$ & & $\delta(\mathrm{O}-\mathrm{Si}-\mathrm{H})$ \\
\hline 893,888 & 893,889 & 894,890 & 890,888 & $\mathrm{~A}_{1}, \mathrm{E}$ & $\mathrm{T}_{2 \mathrm{~g}}$ & 897,883 & $\delta(\mathrm{O}-\mathrm{Si}-\mathrm{H})$ \\
\hline 878,875 & 875,868 & 874,874 & 873,871 & $\mathrm{~A}_{1}, \mathrm{E}$ & $\mathrm{T}_{1 \mathrm{u}}$ & & $\delta(\mathrm{O}-\mathrm{Si}-\mathrm{H})$ \\
\hline,- 841 &,- 839 & 847,842 &,- 840 & $\mathrm{~A}_{2}, \mathrm{E}$ & $\mathrm{T}_{1 \mathrm{~g}}$ & & $\delta(\mathrm{O}-\mathrm{Si}-\mathrm{H})$ \\
\hline 701 & $712 / 707$ & 706 & $726 / 703$ & $\mathrm{E}$ & $\mathrm{E}_{\mathrm{g}}$ & 697 & $v_{\mathrm{sym}}(\mathrm{Si}-\mathrm{O}-\mathrm{Si})$ \\
\hline 684 & 682,682 & $688,684 / 682$ & 685 & $\mathrm{~A}_{2}, \mathrm{E}$ & $\mathrm{T}_{2 \mathrm{u}}$ & & $v_{\mathrm{sym}}(\mathrm{Si}-\mathrm{O}-\mathrm{Si})$ \\
\hline$\sim 616$ & & $597,-$ & & $\mathrm{A}_{1}, \mathrm{E}$ & $\mathrm{T}_{2 \mathrm{~g}}$ & 610 & $v_{\mathrm{sym}}(\mathrm{Si}-\mathrm{O}-\mathrm{Si})$ \\
\hline 571 & 580 & 575 & 575 & $\mathrm{~A}_{1}$ & $\mathrm{~A}_{1 \mathrm{~g}}$ & 580 & $\delta(\mathrm{O}-\mathrm{Si}-\mathrm{O})$ \\
\hline $585,-$ &,- 569 & 532,572 & & $\mathrm{~A}_{1}, \mathrm{E}$ & $\mathrm{T}_{1 \mathrm{u}}$ & & $v_{\mathrm{sym}}(\mathrm{O}-\mathrm{Si}-\mathrm{O})$ \\
\hline \multirow[t]{5}{*}{$461(449)$} & 462 & 455 & 452 & $\mathrm{~A}_{1}$ & $A_{1 g}$ & 456 & $v_{\mathrm{sym}}(\mathrm{O}-\mathrm{Si}-\mathrm{O})$ \\
\hline & 427 & $423 / 427$ & 410,423 & $\mathrm{~A}_{1}, \mathrm{E}$ & $\mathrm{T}_{2 \mathrm{~g}}$ & 414 & $\delta(\mathrm{O}-\mathrm{Si}-\mathrm{O})$ \\
\hline & 412 & 411 & 410 & $\mathrm{E}$ & $\mathrm{E}_{\mathrm{g}}$ & 423 & $\delta(\mathrm{O}-\mathrm{Si}-\mathrm{O})$ \\
\hline & 392 & & 405,389 & $\mathrm{~A}_{1}, \mathrm{E}$ & $\mathrm{T}_{1 \mathrm{u}}$ & & $\delta(\mathrm{O}-\mathrm{Si}-\mathrm{O})$ \\
\hline & & &,- 340 & $\mathrm{~A}_{2}, \mathrm{E}$ & $\mathrm{T}_{1 \mathrm{~g}}$ & 352 & $\delta(\mathrm{O}-\mathrm{Si}-\mathrm{O})$ \\
\hline 329 & 333 & 315 & 314 & $\mathrm{~A}_{1}$ & $\mathrm{~A}_{2 \mathrm{u}}$ & & $\delta(\mathrm{O}-\mathrm{Si}-\mathrm{O})$ \\
\hline 147,173 & $143,172 / 169$ & 187,171 & 173,173 & $\mathrm{~A}_{1}, \mathrm{E}$ & $\mathrm{T}_{2 \mathrm{~g}}$ & 171 & $\delta(\mathrm{O}-\mathrm{Si}-\mathrm{O})$ \\
\hline \multirow[t]{2}{*}{$190 / 187$} & $165 / 157$ & $156 / 140$ & 142 & $\mathrm{E}$ & $\mathrm{E}_{\mathrm{u}}$ & & $\delta(\mathrm{O}-\mathrm{Si}-\mathrm{O})$ \\
\hline & $112 / 97$ & 92 & & $\mathrm{E}$ & $\mathrm{E}_{\mathrm{g}}$ & 84 & $\delta(\mathrm{Si}-\mathrm{O}-\mathrm{Si})$ \\
\hline
\end{tabular}

Ring-Opening Vibrations $\left(\mathbf{4 0 0}-\mathbf{5 0 0} \mathbf{c m}^{-1}\right)$. The IR spectra of all monosubstituted compounds as well as of $\mathrm{H}_{8} \mathrm{Si}_{8} \mathrm{O}_{12}$ show a broad absorption at ca. $470 \mathrm{~cm}^{-1}$ and a sharp one at ca. 400 $\mathrm{cm}^{-1}$ due to ring-opening vibrations. The Raman spectra are dominated by the strong peak at ca. $450 \mathrm{~cm}^{-1}$, which is also due to a ring-opening vibration. This region will be treated more thoroughly in the next section.

Vibrations of the Framework below $400 \mathbf{~ c m}^{-1}$. Below 400 $\mathrm{cm}^{-1}$ only Raman data are available. All monosubstituted compounds show a sharp line between 310 and $340 \mathrm{~cm}^{-1}$, which is strongest for $\left[\mathrm{Co}(\mathrm{CO})_{4}\left(\mathrm{H}_{7} \mathrm{Si}_{8} \mathrm{O}_{12}\right)\right]$ followed by $\mathrm{PhH}_{7} \mathrm{Si}_{8} \mathrm{O}_{12}$. The intensity of this vibration correlates with the contribution of the $\mathrm{Si}-\mathrm{R}$ stretching coordinate, which is considerable in [Co$\left.(\mathrm{CO})_{4}\left(\mathrm{H}_{7} \mathrm{Si}_{8} \mathrm{O}_{12}\right)\right](14 \%)$ and in $\mathrm{Ph}_{7} \mathrm{Si}_{8} \mathrm{O}_{12}(8 \%)$ and can be neglected in $(\mathrm{PhCH}=\mathrm{CH}) \mathrm{H}_{7} \mathrm{Si}_{8} \mathrm{O}_{12}$ and $\left(\mathrm{PhCH}_{2} \mathrm{CH}_{2}\right) \mathrm{H}_{7} \mathrm{Si}_{8} \mathrm{O}_{12}$. This region is only in $\left(\mathrm{PhCH}_{2} \mathrm{CH}_{2}\right) \mathrm{H}_{7} \mathrm{Si}_{8} \mathrm{O}_{12}$ in accordance with $C_{3 v}$ symmetry, all other spectra show additional features.

\section{Ring-Opening Vibrations}

The analysis of $\mathrm{PhH}_{7} \mathrm{Si}_{8} \mathrm{O}_{12}$ and $\mathrm{PhH}_{9} \mathrm{Si}_{10} \mathrm{O}_{15}$ has shown that the notion of ring-opening vibrations is also appropriate in the case of monosubstituted compounds. Ring-opening vibrations are defined as normal modes in which all $\mathrm{Si}-\mathrm{O}$ stretching and/
SCHEME 2: Sets of Equivalent Rings of the Siloxane Cage $\mathrm{RH}_{7} \mathrm{Si}_{8} \mathrm{O}_{12}{ }^{a}$

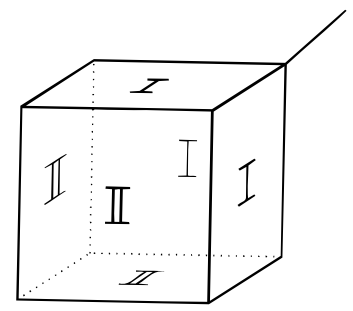

${ }^{a}$ The substituent is treated as a point mass.

or $\mathrm{O}-\mathrm{Si}-\mathrm{O}$ angle bending displacements of the considered ring are in phase. ${ }^{15}$ For octasilasesquioxanes a symmetry reduction from $O_{h}$ to $C_{3 v}$ leads to two sets of equivalent coordinates for $v(\mathrm{Si}-\mathrm{O})$ and $\delta(\mathrm{O}-\mathrm{Si}-\mathrm{O})$. Moreover, the cubes consist of two sets of equivalent rings as shown in Scheme 2.

The ring-opening vibrations of $\mathrm{RH}_{7} \mathrm{Si}_{8} \mathrm{O}_{12}$ with $\mathrm{R}=\mathrm{Ph}$, $\mathrm{CH}=\mathrm{CHPh}, \mathrm{CH}_{2} \mathrm{CH}_{2} \mathrm{Ph}$, and $\mathrm{Co}(\mathrm{CO})_{4}$ were analyzed visually using the computer program $\mathrm{MOBY}^{43}$ and correlated with the ring-opening vibrations of $O_{h}-\mathrm{H}_{8} \mathrm{Si}_{8} \mathrm{O}_{12}$ (Table 7). This analysis revealed in two cases three and in two cases four $A_{1}$ and four E ring-opening vibrations for the monosubstituted compounds. 
TABLE 7: Correlation of the Ring-Opening Vibrations of $\mathrm{RH}_{7} \mathrm{Si}_{8} \mathrm{O}_{12}$ and $\mathrm{H}_{8} \mathrm{Si}_{8} \mathrm{O}_{12}$

\begin{tabular}{|c|c|c|c|c|c|c|c|c|c|c|c|c|}
\hline \multirow{3}{*}{$\begin{array}{c}\mathrm{H}_{8} \mathrm{Si}_{8} \mathrm{O}_{12} \\
\text { calc }\end{array}$} & \multicolumn{11}{|c|}{$\mathrm{RH}_{7} \mathrm{Si}_{8} \mathrm{O}_{12}$} & \\
\hline & \multicolumn{3}{|c|}{$\mathrm{R}=\mathrm{Ph}$} & \multicolumn{3}{|c|}{$\mathrm{R}=\mathrm{CH}=\mathrm{CHPh}$} & \multicolumn{3}{|c|}{$\mathrm{R}=\mathrm{CH}_{2} \mathrm{CH}_{2} \mathrm{Ph}$} & \multicolumn{3}{|c|}{$\mathrm{R}=\mathrm{Co}(\mathrm{CO})_{4}$} \\
\hline & $\overline{\mathrm{IR}}$ & Raman & calc & $\overline{I R}$ & Raman & calc & $\overline{I R}$ & Raman & calc & IR & Raman & $\overline{\text { calc }}$ \\
\hline $\mathrm{A}_{1}$ & & & & & & & & & & & & \\
\hline $\mathrm{T}_{1 \mathrm{u}}(481, \mathrm{rov})$ & 475 & & 478 & 469 & & 477 & 468 & & 486 & 469 & & 480 \\
\hline $\mathrm{A}_{1 \mathrm{~g}}(446, \mathrm{rov})$ & & 462 & 467 & & 455 & 446 & & 452 & 444 & & $\begin{array}{l}461 \\
449\end{array}$ & $\begin{array}{l}468 \\
445\end{array}$ \\
\hline $\mathrm{T}_{2 \mathrm{~g}}(418)$ & & 427 & 430 & & & & & & & & & \\
\hline $\mathrm{T}_{1 \mathrm{u}}(397, \mathrm{rov})$ & 401 & & 403 & 402 & & 402 & 395 & & 393 & 399 & & 402 \\
\hline $\mathrm{T}_{1 \mathrm{u}}(481, \mathrm{rov})$ & 475 & & $500 / 491$ & 469 & & 492 & 468 & & $492 / 490$ & 469 & & 487 \\
\hline $\mathrm{T}_{2 \mathrm{~g}}(418)$ & & 427 & $428 / 425$ & & 427 & $429 / 428$ & & 423 & $430 / 429$ & & & 426 \\
\hline $\mathrm{E}_{\mathrm{g}}(423$, rov $)$ & & 412 & 422 & & 411 & 422 & & 410 & 422 & & & 422 \\
\hline $\mathrm{T}_{1 \mathrm{u}}(397$, rov $)$ & 401 & & 399 & 388 & & 399 & 402 & & 399 & 399 & & 398 \\
\hline
\end{tabular}

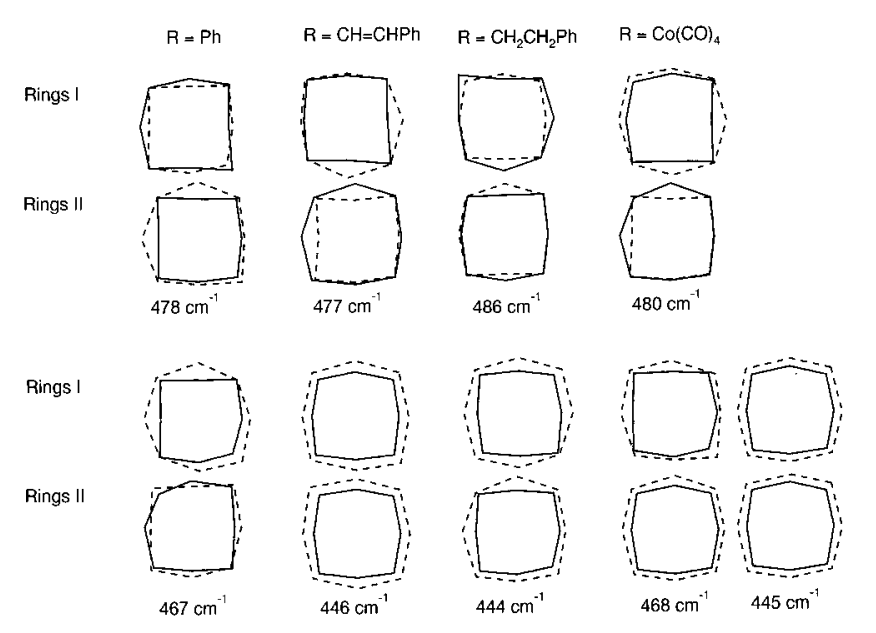

TABLE 8: $\mathrm{Si}-\mathrm{C}$ Stretching Frequencies, Bond Distances, and Force Constants for Different Monosubstituted Octasilasesquioxanes

\begin{tabular}{|c|c|c|c|c|c|c|}
\hline $\begin{array}{l}\text { bond } \\
\text { type }\end{array}$ & $\begin{array}{c}\mathrm{IR} / \\
\mathrm{cm}^{-1}\end{array}$ & $\begin{array}{c}\text { Raman/ } \\
\mathrm{cm}^{-1}\end{array}$ & $\begin{array}{l}\mathrm{calc}^{-1} \\
\mathrm{~cm}^{-1}\end{array}$ & $\begin{array}{c}\% \text { contribution } \\
\text { of } \mathrm{Si}-\mathrm{C} \\
\text { coordinate }\end{array}$ & $\begin{array}{c}F(v(\mathrm{SiC})) / \\
\text { mdyn/A }\end{array}$ & substituent \\
\hline Si- $\mathrm{C}_{\text {alkyl }}$ & $\begin{array}{l}785 \\
790\end{array}$ & 784 & 782 & 39 & 3.03 & $\begin{array}{l}\mathrm{PhCH}_{2} \mathrm{CH}_{2} \\
\mathrm{C}_{6} \mathrm{H}_{13}\end{array}$ \\
\hline Si- $\mathrm{C}_{\text {vinyl }}$ & 821 & 821 & 817 & 49 & 3.36 & $\mathrm{PhCH}=\mathrm{CH}$ \\
\hline Si-C $C_{\text {phenyl }}$ & 730 & 730 & 731 & 30 & 3.39 & \\
\hline Si-C acetyl & & & & & $3.67^{a}$ & $\mathrm{PhC} \equiv \mathrm{C}$ \\
\hline
\end{tabular}
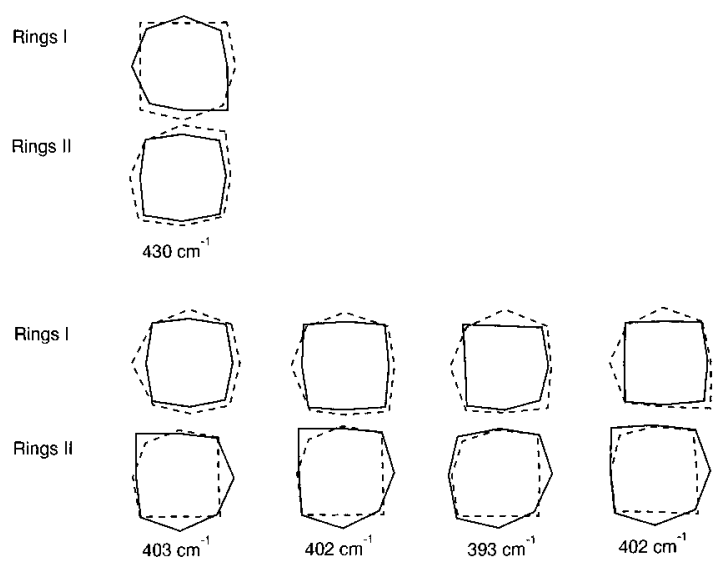

Figure 7. Visual representation of the $A_{1}$ ring-opening vibrations of the investigated $\mathrm{RH}_{7} \mathrm{Si}_{8} \mathrm{O}_{12}$ compounds. The minimal and maximal displacements of the rings I and II, as defined in Scheme 2, are shown. The vibrations correlate from top to bottom with the $\mathrm{T}_{1 \mathrm{u}} v_{\mathrm{s}}(\mathrm{Si}-\mathrm{O}-\mathrm{Si})$ (calc $\left.481 \mathrm{~cm}^{-1}\right)$, the $\mathrm{A}_{1 \mathrm{~g}} \nu_{\mathrm{s}}(\mathrm{Si}-\mathrm{O}-\mathrm{Si})\left(446 \mathrm{~cm}^{-1}\right)$, the $\mathrm{T}_{2 \mathrm{~g}} \delta(\mathrm{O}-\mathrm{Si}-$ O) $\left(418 \mathrm{~cm}^{-1}\right)$, and the $\mathrm{T}_{1 \mathrm{u}} \delta(\mathrm{O}-\mathrm{Si}-\mathrm{O})\left(397 \mathrm{~cm}^{-1}\right)$ of $\mathrm{H}_{8} \mathrm{Si}_{8} \mathrm{O}_{12}$.

The $A_{1}$ ring-opening vibrations are illustrated graphically in Figure 7. For each vibration the minimal and maximal displacements of the rings I and II are shown. In this representation the substituent is connected to the rings $I$ at the down right position. As an effect of the symmetry reduction, the contribution of the $v(\mathrm{Si}-\mathrm{O})$ and/or $\delta(\mathrm{O}-\mathrm{Si}-\mathrm{O})$ coordinates within one ring are different for some ring-opening vibrations, and in the case of $\mathrm{PhH}_{7} \mathrm{Si}_{8} \mathrm{O}_{12}$, the ring-opening movement can be predominately located on either rings I or II. The $\mathrm{A}_{1}$ mode, which correlates with the $\mathrm{T}_{2 \mathrm{~g}} \delta(\mathrm{O}-\mathrm{Si}-\mathrm{O})$ at $418 \mathrm{~cm}^{-1}$ of $\mathrm{H}_{8^{-}}$ $\mathrm{Si}_{8} \mathrm{O}_{12}$, performs only in $\mathrm{PhH}_{7} \mathrm{Si}_{8} \mathrm{O}_{12}$ a ring-opening movement and is therefore illustrated only for this molecule. In $\left[\mathrm{Co}(\mathrm{CO})_{4}{ }^{-}\right.$ $\left(\mathrm{H}_{7} \mathrm{Si}_{8} \mathrm{O}_{12}\right)$ ] two vibrations correlate with the totally symmetric

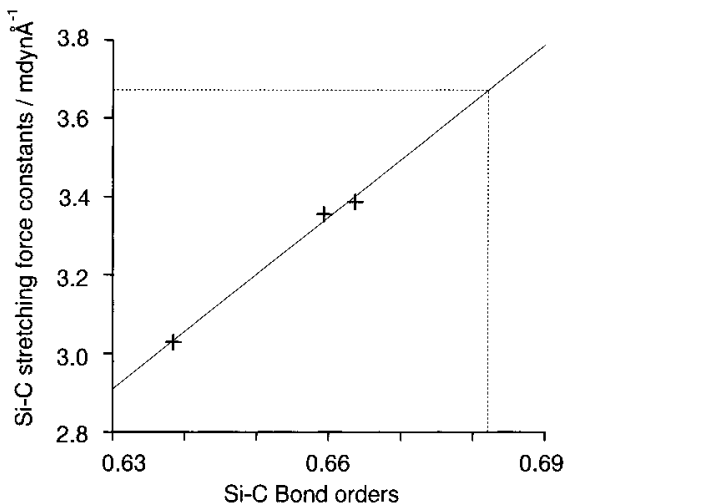

Figure 8. Dependence of the $\mathrm{Si}-\mathrm{C}$ stretching force constants on the $\mathrm{Si}-\mathrm{C}$ bond order. The crosses indicate the values for $\left(\mathrm{PhCH}_{2} \mathrm{CH}_{2}\right) \mathrm{H}_{7^{-}}$ $\mathrm{Si}_{8} \mathrm{O}_{12}, \quad(\mathrm{PhCH}=\mathrm{CH}) \mathrm{H}_{7} \mathrm{Si}_{8} \mathrm{O}_{12}$, and $\mathrm{PhH}_{7} \mathrm{Si}_{8} \mathrm{O}_{12}$. Extrapolation for $(\mathrm{PhC} \equiv \mathrm{C}) \mathrm{H}_{7} \mathrm{Si}_{8} \mathrm{O}_{12}$ leads to a $\mathrm{Si}-\mathrm{C}$ stretching force constant of 3.67 mdyn/Å.

ring-opening vibration calculated at $446 \mathrm{~cm}^{-1}$ in $\mathrm{H}_{8} \mathrm{Si}_{8} \mathrm{O}_{12}$, which are both shown in Figure 7.

A strong dependence on the specific substituent exhibits the totally symmetric ring-opening vibration, which forms a very strong sharp peak at $456 \mathrm{~cm}^{-1}$ in the Raman spectrum of $\mathrm{H}_{8}$ $\mathrm{Si}_{8} \mathrm{O}_{12}$ (calculated at $446 \mathrm{~cm}^{-1}$ ). This peak is the strongest feature in the Raman spectra of $(\mathrm{PhCH}=\mathrm{CH}) \mathrm{H}_{7} \mathrm{Si}_{8} \mathrm{O}_{12}$ and $\left(\mathrm{PhCH}_{2} \mathrm{CH}_{2}\right) \mathrm{H}_{7} \mathrm{Si}_{8} \mathrm{O}_{12}$ and appears at 455 and $452 \mathrm{~cm}^{-1}$, respectively. In $\mathrm{PhH}_{7} \mathrm{Si}_{8} \mathrm{O}_{12}$ it is shifted to $462 \mathrm{~cm}^{-1}$, and its intensity is reduced compared with that of $\mathrm{H}_{8} \mathrm{Si}_{8} \mathrm{O}_{12}$. In $\left[\mathrm{Co}(\mathrm{CO})_{4}\left(\mathrm{H}_{7} \mathrm{Si}_{8} \mathrm{O}_{12}\right)\right]$ two rather strong peaks appear in this region at 461 and $449 \mathrm{~cm}^{-1}$.

The different intensity of this vibration depending on the specific substituent can be qualitatively explained by investigating the potential energy distributions. In $\mathrm{H}_{8} \mathrm{Si}_{8} \mathrm{O}_{12}$ as well as in $\mathrm{RH}_{7} \mathrm{Si}_{8} \mathrm{O}_{12}\left(\mathrm{R}=\mathrm{CH}=\mathrm{CHPh}\right.$ and $\left.\mathrm{CH}_{2} \mathrm{CH}_{2} \mathrm{Ph}\right)$ the $\mathrm{Si}-\mathrm{O}$ stretching coordinate is mainly responsible for this vibration. Figure 7 shows that it performs a strong ring-opening movement of all six 4-rings. In $\mathrm{PhH}_{7} \mathrm{Si}_{8} \mathrm{O}_{12}$ the vibrations at 427 and 462 $\mathrm{cm}^{-1}$ both perform a ring-opening movement, the ring-opening 


\section{SCHEME 3: Three Isomers of $\mathrm{Ph}(\mathrm{PhCH}=\mathrm{CH}) \mathrm{H}_{6} \mathrm{Si}_{8} \mathrm{O}_{12}$}

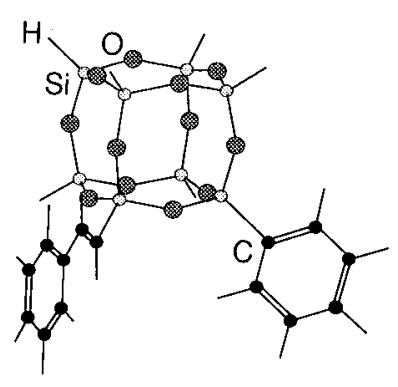

character of the one at $427 \mathrm{~cm}^{-1}$ being due to vibrational coupling with the mode at $462 \mathrm{~cm}^{-1}$. This coupling is confirmed by the PED analysis, which shows a lower contribution of the $\mathrm{Si}-\mathrm{O}$ stretching coordinate for the vibration at 462 $\mathrm{cm}^{-1}$ and a higher for the one at $427 \mathrm{~cm}^{-1}$ compared with the case of $\mathrm{H}_{8} \mathrm{Si}_{8} \mathrm{O}_{12}$. This also leads to the decreased intensity of the mode at $462 \mathrm{~cm}^{-1}$ and the increased intensity of the one at $427 \mathrm{~cm}^{-1}$ as observed in the Raman spectrum (Figure 4). In $\left[\mathrm{Co}(\mathrm{CO})_{4}\left(\mathrm{H}_{7} \mathrm{Si}_{8} \mathrm{O}_{12}\right)\right]$ the PED analysis indicates considerable contributions of the $\mathrm{Si}-\mathrm{O}$ stretching and the axial $\mathrm{CoC}$ stretching coordinates to the vibrations calculated at 468 and $445 \mathrm{~cm}^{-1}$. Both correlate with the totally symmetric ringopening vibration of $\mathrm{H}_{8} \mathrm{Si}_{8} \mathrm{O}_{12}$ at $446 \mathrm{~cm}^{-1}$, forming an in-phase and an out-of-phase combination with $v(\mathrm{CoC})_{\mathrm{ax}}$.

The E ring-opening vibrations of the monosubstituted compounds show a less pronounced dependence on the specific substituents than the $\mathrm{A}_{1}$ modes. In Table 7 it can be seen that one $\mathrm{E}$ mode correlates with the $\mathrm{T}_{2 \mathrm{~g}}$ mode of $\mathrm{H}_{8} \mathrm{Si}_{8} \mathrm{O}_{12}$, which shows no ring-opening character. For $\left[\mathrm{Co}(\mathrm{CO})_{4}\left(\mathrm{H}_{7} \mathrm{Si}_{8} \mathrm{O}_{12}\right)\right]$ the two vibrations calculated at 426 and $422 \mathrm{~cm}^{-1}$ could not be observed in the Raman spectrum as they are covered by the strong $v(\mathrm{CoC})_{\mathrm{eq}}$ peak at $420 \mathrm{~cm}^{-1}$.

\section{Correlation of the $\mathrm{Si}-\mathrm{C}$ Stretching Force Constants and Bond Orders}

The compounds $\mathrm{RH}_{7} \mathrm{Si}_{8} \mathrm{O}_{12}\left(\mathrm{R}=\mathrm{CH}_{2} \mathrm{CH}_{2} \mathrm{Ph}, \mathrm{CH}=\mathrm{CHPh}\right.$, and $\mathrm{Ph}$ ) exemplify $\mathrm{Si}-\mathrm{C}_{\text {alkyl }}, \mathrm{Si}-\mathrm{C}_{\text {vinyl }}$, and $\mathrm{Si}-\mathrm{C}_{\text {phenyl }}$ bonds, respectively. The corresponding stretching frequencies and force constants are listed in Table 8 . The potential energy distribution indicates contributions of the $\mathrm{Si}-\mathrm{C}$ stretching coordinate between 30 and $50 \%$. As different coordinates participate in these vibrations, the frequency positions will be influenced by contributions from several coordinates, and it is therefore not possible to deduce a trend for the $\mathrm{Si}-\mathrm{C}$ bond orders on the basis of the measured frequencies. In the case of $\mathrm{PhH}_{7} \mathrm{Si}_{8} \mathrm{O}_{12}$ also a mass effect could be responsible for the low $\mathrm{Si}-\mathrm{C}$ stretching frequency, the higher mass in this case being due to the direct connection of the phenyl ring to the siloxane cage. More representative for the bond strengths than the frequencies are the force constants. Table 8 shows that the force constants indicate indeed a different trend than the frequencies with a stronger $\mathrm{Si}-\mathrm{C}$ bond for $\mathrm{Si}-\mathrm{C}_{\text {phenyl }}$ and $\mathrm{Si}-\mathrm{C}_{\text {vinyl }}$ than $\mathrm{Si}-\mathrm{C}_{\text {alkyl. }}$ It seemed therefore interesting to compare the force constant trend with the $\mathrm{Si}-\mathrm{C}$ bond orders of $\mathrm{RH}_{7} \mathrm{Si}_{8} \mathrm{O}_{12}(\mathrm{R}=$ $\mathrm{CH}_{2} \mathrm{CH}_{2} \mathrm{Ph}, \mathrm{CH}=\mathrm{CHPh}$, and $\mathrm{Ph}$ ) calculated by the EHMO method. ${ }^{44}$ For this calculation the same parameters were used as in ref 45 . Figure 8 shows that the force constants and the bond orders both increase in the series $\mathrm{Si}-\mathrm{C}_{\text {alkyl }}, \mathrm{Si}-\mathrm{C}_{\text {vinyl }}, \mathrm{Si}-$ $\mathrm{C}_{\text {phenyl. }}$. The extrapolation for $(\mathrm{PhC} \equiv \mathrm{C}) \mathrm{H}_{7} \mathrm{Si}_{8} \mathrm{O}_{12}$ leads to a force constant value $F\left(v\left(\mathrm{SiC}_{\text {acetyl }}\right)\right)=3.67 \mathrm{mdyn} / \AA$.

\section{Conclusions}

The IR and Raman spectra of the monosubstituted hydrosilasesquioxanes $\mathrm{RH}_{7} \mathrm{Si}_{8} \mathrm{O}_{12}\left(\mathrm{R}=\mathrm{Co}(\mathrm{CO})_{4}, \mathrm{Ph}, \mathrm{CH}=\mathrm{CHPh}\right.$, and $\mathrm{CH}_{2} \mathrm{CH}_{2} \mathrm{Ph}$ ) have been analyzed by spectral correlation and a normal coordinate analysis. Special attention was paid to the $\mathrm{Si}-\mathrm{C}$ stretching and the ring-opening vibrations. Although most spectral features of the siloxane cages could be understood assuming a local $C_{3 v}$ symmetry, vibrations indicating a lower symmetry occurred in all monosubstituted compounds and were due to vibrational coupling with modes of the substituent. Especially the totally symmetric ring-opening vibration at 456 $\mathrm{cm}^{-1}$ in the Raman spectrum of $\mathrm{H}_{8} \mathrm{Si}_{8} \mathrm{O}_{12}$ showed a specific dependence on the different substituents. The molecules $\mathrm{PhH}_{7^{-}}$ $\mathrm{Si}_{8} \mathrm{O}_{12},(\mathrm{PhCH}=\mathrm{CH}) \mathrm{H}_{7} \mathrm{Si}_{8} \mathrm{O}_{12}$, and $\left(\mathrm{PhCH}_{2} \mathrm{CH}_{2}\right) \mathrm{H}_{7} \mathrm{Si}_{8} \mathrm{O}_{12}$ have allowed the investigation of the organic-substituted siloxane cage $\mathrm{CH}_{7} \mathrm{Si}_{8} \mathrm{O}_{12}$, contributing each a case of an $\mathrm{Si}-\mathrm{C}_{\text {phenyl }}, \mathrm{Si}-\mathrm{C}_{\text {vinyl }}$, and $\mathrm{Si}-\mathrm{C}_{\text {alkyl }}$ bond, respectively. To complete this series, an $\mathrm{Si}-\mathrm{C}$ stretching force constant was extrapolated for $(\mathrm{PhC} \equiv \mathrm{C})$ $\mathrm{H}_{7} \mathrm{Si}_{8} \mathrm{O}_{12}$. The silasesquioxane $\left[\mathrm{Co}(\mathrm{CO})_{4}\left(\mathrm{H}_{7} \mathrm{Si}_{8} \mathrm{O}_{12}\right)\right]$, which exhibits a silicon-metal bond, could be analyzed the same way as the organic-substituted compounds and showed a similar pattern for the siloxane cage vibrations.

This analysis forms the basis for the investigation of the siloxane cage vibrations occurring in disubstituted octahydrosilasesquioxanes $\mathrm{R}^{\prime} \mathrm{R}^{\prime \prime} \mathrm{H}_{6} \mathrm{Si}_{8} \mathrm{O}_{12}$ and for the study of the vibrational interactions between the two substituents $\mathrm{R}^{\prime}$ and $\mathrm{R}^{\prime \prime}$ in these systems. Three isomers exist in the case of disubstitution as shown in Scheme 3 for $\mathrm{R}^{\prime}=\mathrm{Ph}$ and $\mathrm{R}^{\prime \prime}=\mathrm{CH}=\mathrm{CHPh}$. These compounds should become available by hydrosilation of a monosubstituted hydrosilasesquioxane and subsequent separation of the mixtures. ${ }^{46}$

Acknowledgment. This work was supported by the Schweizerischer Nationalfonds zur Förderung der wissenschaftlichen Forschung (Project NF 20-46617.96).

\section{References and Notes} 199.

(1) Voronkov, M. G.; Lavrent'yev, V. I. Top. Curr. Chem. 1982, 102,

(2) Mehl, G. H.; Goodby, J. W. Angew. Chem. 1996, 108, 2791.

(3) Bassindale, A. R.; Gentle, T. E. J. Mater. Chem. 1993, 3, 1319.

(4) Hoebbel, D.; Pitsch, I.; Heidemann, D. Z. Anorg. Allg. Chem. 1991, 592, 207.

(5) Haddad, T. S.; Lichtenhan, J. D. J. Inorg. Organomet. Polym. 1995, 5,237

(6) Agaskar, P. A. J. Am. Chem. Soc. 1989, 111, 6858.

(7) Agaskar, P. A. Inorg. Chem. 1990, 29, 1603.

(8) Yuchs, S. E.; Carrado, K. A. Inorg. Chem. 1996, 35, 261.

(9) Harrison, P. G.; Kannengiesser, R. J. Chem. Soc., Chem. Commun. 1995, 2065.

(10) Sellinger, A.; Laine, R. M. Chem. Mater. 1996, 8, 1592.

(11) Sellinger, A.; Laine, R. M. Macromolecules 1996, 29, 2327. 1691. 
(13) Bieniok, A. M.; Bürgi, H.-B. J. Phys. Chem. 1994, 98, 10735.

(14) Bärtsch, M.; Bornhauser, P.; Calzaferri, G.; Imhof, R. J. Phys. Chem. 1994, 98, 2817.

(15) Bornhauser, P.; Calzaferri, G. J. Phys. Chem. 1996, 100, 2035.

(16) de Man, A. J. M.; Sauer, J. J. Phys. Chem. 1996, 100, 5025.

(17) Tossell, J. A. J. Phys. Chem. 1996, 100, 14828.

(18) Pasquarello, A.; Hybertsen, M. S.; Car, R. Phys. Rev. 1996, B54 R2339.

(19) Auf der Heyde, T. P. E.; Bürgi, H.-B.; Bürgy, H.; Törnroos, K. W. Chimia 1991, 45, 38.

(20) Törnroos, K. W. Acta Crystallogr. 1994, C50, 1646.

(21) Kowalewski, J.; Nilsson, T., Törnroos, K. W. J. Chem. Soc., Dalton Trans. 1996, 1597.

(22) Marcolli, C.; Lainé, P.; Bühler, R.; Calzaferri, G.; Tomkinson, J. J. Phys. Chem. B 1997, 101, 1171.

(23) Calzaferri, G.; Herren, D.; Imhof, R. Helv. Chim. Acta 1991, 74, 1278 . 33.

(25) Dittmar, U.; Hendan, B. J.; Flörke, U.; Marsmann, H. C. J. Organomet. Chem. 1995, 489, 185.

(26) Bürgy, H.; Calzaferri, G. J. Chromatogr. 1990, 507, 481.

(27) Calzaferri, G.; Imhof, R.; Törnroos, K. W. J. Chem. Soc., Dalton Trans. 1993, 3741.

(28) Calzaferri, G.; Imhof, R.; Törnroos, K. W. J. Chem. Soc., Dalton Trans. 1994, 3123.

(29) Calzaferri, G.; Marcolli, C.; Imhof, R.; Törnroos, K. W. J. Chem. Soc., Dalton Trans. 1996, 3313.
(30) Marcolli, C.; Imhof, R.; Calzaferri, G. Microchim. Acta 1997 (Suppl. 14), 493.

(31) Wilson, E. B., Jr.; Decius, J. C.; Cross, P. C. Molecular Vibrations; McGraw-Hill Book Co.: New York, 1955.

(32) McIntosh, D. F.; Peterson, M. R. General Vibrational Analysis System; QCPE Program No. QCMP067, 1988.

(33) van den Berg, G. C.; Oskam, A. J. Organomet. Chem. 1974, 78, 357.

(34) Marcolli, C. Ph.D. Thesis, Universität Bern, 1996.

(35) Calzaferri, G.; Brändle, M. QCMP No. 116. QCPE Bull. 1992, 12 (4) (update May 1993).

(36) Calzaferri, G.; Rytz, R. J. Phys. Chem. 1996, 100, 11122.

(37) van den Berg, G. C.; Oskam, A.; Vrieze, K. J. Organomet. Chem. 1973, 57, 329.

(38) van den Berg, G. C.; Oskam, A. J. Organomet. Chem. 1975, 91, 1.

(39) Darensbourg, D. J.; Brown, T. L. Inorg. Chem. 1968, 7, 959.

(40) Brown, T. L.; Darensbourg, D. J. Inorg. Chem. 1967, 6, 971.

(41) Darensbourg, D. J. Inorg. Chim. Acta 1970, 4, 597.

(42) Bor, G. Inorg. Chim. Acta 1967, 1, 81.

(43) Höweler, U. MOBY, Molecular Modelling on the PC, Version 1.6F. Springer-Verlag: Berlin, 1993.

(44) Hoffmann, R. J. Chem. Phys. 1963, 39, 1397.

(45) Bärtsch, M.; Calzaferri, G.; Marcolli, C. Res. Chem. Intermed. 1995, $21,577$.

(46) Aebi, B.; Calzaferri, G.; Herren, D.; Imhof, R.; Schlunegger, U. P. Rapid Commun. Mass Spectrom. 1996, 10, 1607. 